Nixon, A. E., R. J. Fisher, D. Stralberg, E. M. Bayne, and D. Farr. 2016. Projected responses of North American grassland songbirds to climate change and habitat availability at their northern range limits in Alberta, Canada. Avian Conservation and Ecology 11(2):2. http://dx.doi.org/10.5751/ ACE-00866-110202

Copyright (C) 2016 by the author(s). Published here under license by the Resilience Alliance.

Research Paper

\title{
Projected responses of North American grassland songbirds to climate change and habitat availability at their northern range limits in Alberta, Canada
}

\author{
Amy E. Nixon ${ }^{1}$, Ryan J. Fisher ${ }^{2,3}$, Diana Stralberg ${ }^{2,4}$, Erin M. Bayne ${ }^{2}$ and Dan R. Farr ${ }^{1}$ \\ ${ }^{1}$ Alberta Biodiversity Monitoring Institute, ${ }^{2}$ Department of Biological Sciences, University of Alberta, Edmonton, AB, ${ }^{3}$ Fish and \\ Wildlife Branch, Saskatchewan Ministry of Environment, Regina, SK, ${ }^{4}$ Department of Renewable Resources, University of \\ Alberta, Edmonton, AB
}

\begin{abstract}
Across North America, grassland songbirds have undergone steep population declines over recent decades, commonly attributed to agricultural intensification. Understanding the potential interactions between the impacts of climate change on the future distributions of these species and the availability of suitable vegetation for nesting can support improved risk assessments and conservation planning for this group of species. We used North American bioclimatic niche models to examine future changes in suitable breeding climate for 15 grassland songbird species at their current northern range limits along the boreal forest-prairie ecotone in Alberta, Canada. Our climate suitability projections, combined with the current distribution of native and tame pasture and cropland in Alberta, suggest that some climate-mediated range expansion of grassland songbirds in Alberta is possible. For six of the eight species projected to experience expansions of suitable climate area in Alberta, this suitable climate partly overlaps the current distribution of suitable land cover. Additionally, for more than half of the species examined, most of the area of currently suitable climate was projected to remain suitable to the end of the century, highlighting the importance of Alberta for the long-term persistence of these species. Some northern prairie-endemic species exhibited substantial projected northward shifts of both the northern and southern edges of the area of suitable climate. Baird's Sparrow (Ammodramus bairdii) and Sprague's Pipit (Anthus spragueii), both at-risk grassland specialists, are predicted to have limited climate stability within their current ranges, and their expansion into new areas of suitable climate may be limited by the availability of suitable land cover. Our results highlight the importance of the preservation and restoration of remaining suitable grassland habitat within areas of projected climate stability and beyond current northern range limits for the long-term persistence of many grassland songbird species in the face of climate change.
\end{abstract}

\section{Réactions projetées de passereaux de prairie nord-américains aux changements climatiques et à la disponibilité de I'habitat à la limite nord de leur aire en Alberta, Canada}

RÉSUMÉ. Partout en Amérique du Nord, les passereaux de prairie ont subi d'importantes baisses de population au cours des dernières décennies, qu'on attribue le plus souvent à l'intensification de l'agriculture. La compréhension des interactions potentielles entre les impacts des changements climatiques sur la future répartition de ces espèces et la disponibilité de végétation favorable à leur nidification peut contribuer à améliorer l'évaluation des risques et la planification des mesures de conservation pour ce groupe d'espèces. Nous avons utilisé des modèles de niches bioclimatiques afin d'examiner les variations futures du climat favorable pour la nidification de 15 passereaux de prairie à la limite nord de leur aire actuelle le long de l'écotone forêt boréale-prairie en Alberta, au Canada. Nos projections du caractère favorable du climat, combinées à la répartition actuelle des pâturages naturels et artificiels et des terres cultivées en Alberta, indiquent qu'une certaine expansion d'aire régie par le climat est possible pour les passereaux de prairie en Alberta. Chez six des huit espèces pour lesquelles nous projetons une expansion de l'étendue de climat favorable en Alberta, ce climat favorable chevauche en partie la répartition actuelle de couverture au sol convenable. De plus, chez plus de la moitié des espèces examinées, nous avons projeté que la majorité de l'étendue de climat favorable actuel resterait favorable jusqu'à la fin du présent siècle, soulignant l'importance de l'Alberta pour la persistance à long terme de ces espèces. Pour certaines espèces de prairie endémiques septentrionales, des déplacements substantiels vers le nord ont été projetés, tant pour la bordure nord que pour la bordure sud de l'étendue de climat favorable. Nous avons prédit que le Bruant de Baird (Ammodramus bairdii) et le Pipit de Sprague (Anthus spragueii), deux spécialistes de prairie en péril, feraient face à une stabilité climatique restreinte dans leurs aires courantes, et leur expansion dans de nouvelles étendues de climat favorable pourrait être limitée par la disponibilité de couverture au sol convenable. Nos résultats mettent en lumière l'importance de préserver et de restaurer les milieux de prairie favorables restants dans les étendues de climat stable projeté et au-delà de la limite nord actuelle des aires de répartition afin d'assurer la persistance à long terme de nombreux passereaux de prairie malgré les changements climatiques.

Key Words: grassland; land cover; MaxEnt; northern Great Plains; songbird; species distribution modeling

Address of Correspondent: Amy E Nixon, CW 405 Biological Sciences Building, University Of Alberta, Edmonton, AB , Canada, T6G 2E9, aenixon@ualberta.ca 


\section{INTRODUCTION}

Grassland birds have undergone steep population declines across North America in recent decades (Sauer and Link 2011, NABCI 2014), which have been linked to land use changes, especially agricultural intensification resulting in grassland degradation (Askins et al. 2007). Consequently, grassland birds are among the most at-risk avian groups in North America (NABCI 2014). The impacts of historical, current, and future land use changes on grassland birds may be compounded by and will interact with their responses to climate change (Staudt et al. 2013). The tight linkages between grassland bird distributions and climate and yearly weather conditions in North America (Wiens 1974, Rotenberry and Wiens 1991, Niemuth et al. 2008), combined with their high mobility, may enable distributional shifts in response to climate change when new areas of suitable climate and vegetation become available, or existing habitat becomes unsuitable (Skagen and Adams 2012). Across North America, northward shifts in songbird breeding ranges have already occurred in response to climate change (Hitch and Leberg 2007, Zuckerberg et al. 2009, Coristine and Kerr 2015).

Where the potential responses of North American grassland birds to future climate change have been examined, projections indicate expansions of suitable climate area for some species and predicted increases in the abundance of grassland-associated species in the boreal regions (Langham et al. 2015, Stralberg et al. 2015a). Conversely, potentially severe declines in suitable climate area in North America have been projected for other species (Langham et al. 2015). The persistence of grassland songbirds in a changing climate will depend, however, on several factors: the continued suitability of climate within their current ranges, the potential changes in the distribution of suitable climate, and the birds' ability to colonize new areas of suitable climate beyond their current northern range edges. To date, the effect of the availability of suitable land cover on the projected changes in grassland songbird distributions with climate change have not been considered.

Currently, the northern edges of many grassland songbird ranges approach the prairie-boreal forest ecotone, where suitable grassland or agricultural habitat transitions to unsuitable forest habitat. While climate change may cause northward shifts in suitable climate area for grassland songbirds, lags in the transition of forested ecosystems to suitable grassland vegetation may limit the ability of birds to respond in parallel (Stralberg et al. 2015b). In the absence of grassland to cropland conversion, grasslands that currently support songbird populations in their northern range extent are likely to remain important habitat over the next century. Climate-driven changes in those native grassland communities will likely be limited primarily to transitions toward southern Great Plains communities (Rehfeldt et al. 2012), including warm-season grass and shrub-steppe communities (Thorpe 2011). Similarly, non-native agricultural communities and annual cropland are likely to remain as suitable land cover for some species, even as climate changes. Therefore, if projected shifts in suitable climate area for grassland songbirds correspond with currently suitable land cover, the persistence and potential range expansions of these species may be facilitated. If suitable climate area for grassland songbirds shifts outside the current distribution of suitable land cover (i.e., expands into the current boreal region), and lags in native vegetation transition occur, expansion by grassland songbirds into new areas may be limited.
We used bioclimatic niche models to project the distributional responses of 15 grassland songbird species to changes in climate over the next century, and examined differences among baseline (1961-1990) and future time periods (2041-2070 and 2071-2100) to identify potential changes in the amount and location of suitable breeding climate for these species across North America. As a case study, we used the distribution projections in the province of Alberta, Canada $\left(6.6 \times 10^{5} \mathrm{~km}^{2}\right)$ to examine the stability of the current distributions of grassland songbirds and the potential for range expansions along their northern range limits. This region currently contains the northern range edges for many grassland songbirds and a large proportion of the breeding ranges for several range-restricted species (e.g., Sprague's Pipit [Anthus spragueii]) (Davis et al. 2014). Additionally, dramatic change in the southern boreal forest in Alberta is projected in response to climate change, including expansion of climates suitable for grassland habitats (Rehfeldt et al. 2012). Potential interactions between climate-driven distribution changes and the availability of suitable land cover are likely to be most relevant along northern range edges and in areas with large projected changes in regional ecosystems. Furthermore, northwestern Alberta contains the Peace River parkland, a large, northern region of former native grassland that has been largely converted to agriculture and that is surrounded by boreal vegetation (Natural Regions Committee 2006); this region may provide suitable habitat for northward expansion of some grassland songbirds. To identify how the current distribution of grassland and agricultural land cover may facilitate or limit potential songbird distribution shifts in Alberta, we examined the degree of correspondence between projected climate suitability and land cover types in Alberta. The combined assessment of suitable climate area projections, the climate stability of current ranges, and the potential influence of land cover to either facilitate or limit climate-driven distribution shifts provides a more complete understanding of the potential climate vulnerabilities and opportunities faced by these species, and can be used to incorporate climate change considerations into management and conservation planning.

\section{METHODS}

\section{Avian survey data and study area}

We compiled data from avian surveys conducted throughout Canada, the continental United States, and Alaska for 15 grassland songbird species routinely observed in the northern Great Plains (Table 1). The compiled data came primarily from two sources: roadside point counts conducted as part of the North American Breeding Bird Survey (BBS) (Sauer et al. 2014) in 19672014, and species checklist data from the Western Hemisphere eBird reference data set that span 1947-2012 (Sullivan et al. 2009, Munson et al. 2013). We limited observations from the BBS to those with exact stop locations (22,085 stops from 780 routes in 32 provinces and northern states). Observations from the eBird data set were limited to June observations, and included only stationary, traveling, and area search surveys (we omitted incidental or casual observations). We further limited eBird surveys to those where the area surveyed was less than the spatial resolution of the climate data $(4 \mathrm{~km} \times 4 \mathrm{~km})$, so that we could be reasonably certain that the survey occurred within a single grid cell. These data were supplemented with off-road point-count surveys from avian monitoring conducted by the Alberta 
Table 1. Habitat use, specialization, and number of occurrences used in climate suitability modeling for 15 grassland songbird species.

\begin{tabular}{|c|c|c|c|c|c|}
\hline Common name & Scientific name & $\begin{array}{l}\mathrm{AOU} \\
\operatorname{code}^{\dagger}\end{array}$ & Habitat $^{*}$ & Specialization $^{\S}$ & $\begin{array}{l}\text { Occurrence } \\
\text { locations }\end{array}$ \\
\hline Baird's Sparrow & Ammodramus bairdii & BAIS & $G$ & Endemic & 1741 \\
\hline Bobolink & Dolichonyx oryzivorus & BOBO & $\mathrm{G}$ & Secondary & 10472 \\
\hline Brewer's Sparrow & Spizella breweri & BRSP & G & Secondary & 2222 \\
\hline Chestnut-collared Longspur & Calcarius ornatus & CCLO & G & Endemic & 1640 \\
\hline Clay-colored Sparrow & Spizella pallida & CCSP & G & Secondary & 9913 \\
\hline Grasshopper Sparrow & Ammodramus savannarum & GRSP & $\mathrm{G}$ & Secondary & 7192 \\
\hline Horned Lark & Eremophila alpestris & HOLA & $\mathrm{G} / \mathrm{C}$ & Secondary & 14274 \\
\hline Lark Bunting & Calamospiza melanocorys & LARB & G & Endemic & 2020 \\
\hline Lark Sparrow & Chondestes grammacus & LASP & $\mathrm{G}$ & Secondary & 3523 \\
\hline Le Conte's Sparrow & Ammodramus leconteii & LCSP & $\mathrm{G}$ & Secondary & 2093 \\
\hline McCown's Longspur & Rhynchophanes mccownii & MCLO & G & Endemic & 537 \\
\hline Savannah Sparrow & Passerculus sandwichnesis & SAVS & $\mathrm{G} / \mathrm{C}$ & Secondary & 21803 \\
\hline Sprague's Pipit & Anthus spragueii & SPPI & $\mathrm{G}$ & Endemic & 2094 \\
\hline Vesper Sparrow & Pooecetes gramineus & VESP & $\mathrm{G} / \mathrm{C}$ & Secondary & 14235 \\
\hline Western Meadowlark & Sturnella neglecta & WEME & $\mathrm{G}$ & Secondary & 16336 \\
\hline
\end{tabular}

AOU: American Ornithological Union

G: native and tame grassland/hay; C: annual cropland. Refer to Table A1.1 for classification rationale.

${ }^{\S}$ Described by Knopf (1994). Endemic species are those thought to have evolved within the Great Plains, typically within specific ecological niches within the grasslands; secondary species are those considered secondarily evolved to grasslands that are typically more widespread, or more closely associated with other ecoregions (e.g., Brewer's Sparrow and the Great Basin shrubsteppe). Le Conte's Sparrow and Bobolink are not classified by Knopf (1994); both species have widespread distributions beyond the Great Plains, so are classified as secondary species here.

Biodiversity Monitoring Institute in 2003-2014 and from research projects conducted in Alberta and Saskatchewan, Canada between 2005 and 2007 (Davis et al. 2013). The resulting data set included observations from 39,063 unique locations. Species observations were summarized across years as the occurrence of each species at each location; the number of occurrence locations ranged from 537 (McCown's Longspur) to 21,803 (Savannah Sparrow) (Table 1).

We limited the modeling extent to that of the surveyed locations, which included analogous future climates for all but the southernmost portion of the study area (Rehfeldt et al. 2012) (Fig. 1A). The southern limit was defined by the Mexico-United States border, and the northern limit by the level II ecoregions of North America (CEC 1997) that delimit the southern Arctic.

\section{Climate data}

To construct the bioclimatic niche models and future projections, we used available historical baseline and projected future climate data for North America (data supplement to Stralberg et al. 2015a). These data comprise interpolated climate data at a $4-\mathrm{km}$ resolution for the 1961-1990 baseline period based on the PRISM model (Daly et al. 2008) and downscaled projections for two 30year future periods (2041-2070 and 2071-2100). The future climate projections were based on global climate model (GCM) projections from the CMIP3 multi-model data set associated with the fourth Intergovernmental Panel on Climate Change assessment report (Meehl et al. 2007), from which projected anomalies were added to the $4-\mathrm{km}$ baseline data using the delta method and bilinear interpolation (Wang et al. 2012). We selected data from four complementary GCMs to represent a range of projected future climates for North America (Stralberg et al. 2015a): the German ECHAM5/MPI-OM, the Canadian CCCMA-CGCM3.1(T47), the American GFDL-CM2.1, and the United Kingdom UKMO- HadGEM1. In addition, we used an ensemble mean climate projection derived from 19 GCMs. We adopted the SRES A2 emissions scenario (IPCC 2001), which most closely reflects the current trend in global carbon emissions (Friedlingstein et al. 2014).

We relied on a subset of seven bioclimatic variables from the climate data set (Table 2), which was selected to avoid extreme collinearity (Dormann et al. 2012), prioritize seasonal over annual variables, or include variables relevant to vegetation communities. We retained some variables with high correlations because our objective was prediction, rather than interpretation (Dormann et al. 2012), and because machine-learning modeling methods are relatively robust to correlated covariates (Merow et al. 2013). Within the model building data set (surveyed grid cells), the most highly correlated variables were summer climate moisture index and annual climate moisture index $(r=0.88)$.

Table 2. Ranked predictor variable importance across all 15 species, determined from the ranked bootstrap-averaged single variable $\mathrm{AUCs}^{\dagger}$ for each species.

\begin{tabular}{|c|c|}
\hline Rank & Variable description \\
\hline 1 & $\begin{array}{l}\text { Annual climate moisture index (modified Penmnan-Monteith } \\
\text { method) }\end{array}$ \\
\hline 2 & Mean summer (May to September) precipitation (mm) \\
\hline 3 & Extreme minimum temperature over 30 years $\left({ }^{\circ} \mathrm{C}\right)$ \\
\hline 4 & $\begin{array}{l}\text { Summer (June to August) climate moisture index (modified } \\
\text { Penman-Monteith method) }\end{array}$ \\
\hline 5 & Degree-days above $5^{\circ} \mathrm{C}$ (growing degree days) \\
\hline 6 & Degree-days below $0^{\circ} \mathrm{C}$ (chilling degree days) \\
\hline 7 & $\begin{array}{l}\text { Difference between the mean temperature of the coldest month } \\
\text { and the mean temperature of the warmest month, as a measure } \\
\text { of continentality }\left({ }^{\circ} \mathrm{C}\right)\end{array}$ \\
\hline
\end{tabular}


Fig. 1. (A) Model extent and distribution of background points used to model climate suitability for grassland songbirds in North America. (B) Distribution of crop and native/tame grassland and hayland cover in Alberta (Agriculture and Agri-Food Canada 2013).

A

\section{Legend \\ - Background points \\ Model extent \\ Alberta boundary}

B

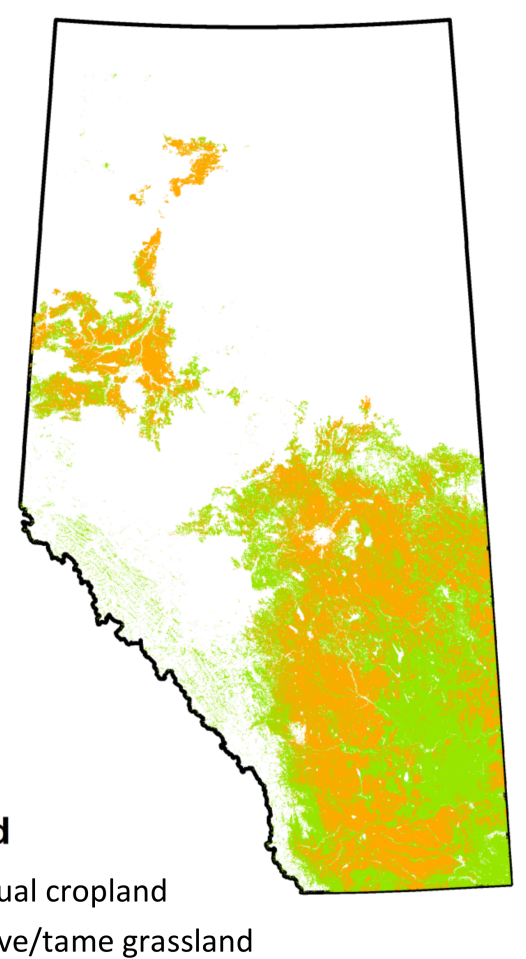

\section{Bioclimatic niche modeling}

We used the maximum entropy method of bioclimatic niche modeling to generate predictions of current climate suitability for the baseline period and projections of climate suitability for both future 30-year time periods (MaxEnt v. 3.3.3) (Phillips et al. 2006, Elith et al. 2011). MaxEnt is a machine-learning algorithm, widely used as a robust approach to bioclimatic niche modeling based on species occurrence records (Elith et al. 2011). We used this presence-only modeling approach because we could not assume absence at the $4 \mathrm{~km} \mathrm{x} 4 \mathrm{~km}$ grid-cell level used to build models (based on climate data resolution).

Occurrence records were aggregated across survey locations within each $4 \mathrm{~km} \mathrm{x} 4 \mathrm{~km}$ grid cell of the climate data, thereby reducing nonindependence between records. To accommodate potential sampling bias in the species occurrence data (e.g., due to spatial aggregation of survey locations, or associated with roadside sampling) (Wellicome et al. 2014), we restricted our background points to surveyed grid cells $(n=15,534)$ (Phillips et al. 2009) (Fig. 1).

Species models were constructed in MaxEnt from 50 replicates using linear, quadratic, product, and threshold features to accommodate potential nonlinearities in interactions among predictors. Each of these features is a transformation of the covariates used to constrain the model: the covariates themselves, the squares of the covariates, the interactions between two covariates, and step functions of the covariates equivalent to a piecewise constant spline, respectively (Phillips et al. 2006). In each replicate, occupied grid cells were randomly assigned into training $(70 \%)$ and testing $(30 \%)$ data sets. All other settings were left at the default values. Replicate models for each species were projected onto the baseline and future climates across North America, and then averaged to predict climate suitability in each set of climate conditions. Relative climate suitability was determined from the MaxEnt cumulative output, which represents the empirical cumulative probability distribution function and ranges from 100, representing perfect suitability, to 0 , representing unsuitable conditions (Phillips et al. 2006).

\section{Model performance}

Model performance was evaluated using the area under the curve of the receiver operating characteristic plot (ROC AUC) (Fielding and Bell 1997); an AUC > 0.7 indicates good model performance, whereas an $\mathrm{AUC}=0.5$ indicates a model with predictive capability no better than chance (Manel et al. 2001). AUC is a widely used, but imperfect measure, of model performance for presenceabsence and presence-only models (Lobo et al. 2008, Merow et al. 2013). For MaxEnt models, AUC is a measure of how the model distinguishes between occurrences and background points (Elith et al. 2011). Therefore, models of widespread species that occupy a large proportion of the background points (here, all surveyed locations) will necessarily have lower AUC values than those of species with more localized distributions (Lobo et al. 2008). Our selection of background cells based on locations where at least one grassland bird species was observed reduced AUC values, relative to evaluation against a broader set of background points. 
Table 3. Predictive performance of average MaxEnt models for each grassland songbird species. Average models are based on 50 bootstrapped replicates with a 70\%-30\% training-testing split of the occupied $4 \times 4 \mathrm{~km}$ grid cells $(n)$ in each replicate. Sensitivity and specificity were evaluated using the threshold that maximized the sum of sensitivity and specificity for each species. Sensitivity was evaluated using the threshold identified from the training data set applied to the test data set. Specificity was evaluated using the same threshold, applied to all unoccupied background cells.

\begin{tabular}{|c|c|c|c|c|c|c|c|}
\hline Species & $n$ & $\begin{array}{c}\text { Test } \\
\text { AUC }^{\dagger}\end{array}$ & $\mathrm{SD}$ & $\begin{array}{c}\text { Test } \\
\text { sensitivity }\end{array}$ & $\mathrm{SD}$ & Specificity & $\mathrm{SD}$ \\
\hline Baird's Sparrow & 706 & 0.951 & 0.003 & 0.951 & 0.020 & 0.922 & 0.009 \\
\hline Bobolink & 4299 & 0.777 & 0.005 & 0.873 & 0.018 & 0.767 & 0.014 \\
\hline Brewer's Sparrow & 783 & 0.927 & 0.005 & 0.910 & 0.022 & 0.864 & 0.011 \\
\hline Chestnut-collared Longspur & 667 & 0.953 & 0.004 & 0.954 & 0.022 & 0.918 & 0.008 \\
\hline Clay-colored Sparrow & 3810 & 0.832 & 0.004 & 0.880 & 0.014 & 0.896 & 0.006 \\
\hline Grasshopper Sparrow & 3154 & 0.776 & 0.007 & 0.764 & 0.029 & 0.773 & 0.025 \\
\hline Horned Lark & 5281 & 0.699 & 0.006 & 0.694 & 0.031 & 0.757 & 0.030 \\
\hline Lark Bunting & 704 & 0.946 & 0.005 & 0.914 & 0.027 & 0.910 & 0.013 \\
\hline Lark Sparrow & 1965 & 0.839 & 0.006 & 0.827 & 0.028 & 0.788 & 0.021 \\
\hline Le Conte's Sparrow & 1211 & 0.901 & 0.004 & 0.925 & 0.016 & 0.852 & 0.007 \\
\hline McCown's Longspur & 272 & 0.966 & 0.005 & 0.927 & 0.043 & 0.929 & 0.018 \\
\hline Savannah Sparrow & 8117 & 0.654 & 0.005 & 0.812 & 0.037 & 0.699 & 0.034 \\
\hline Sprague's Pipit & 790 & 0.939 & 0.004 & 0.930 & 0.024 & 0.885 & 0.011 \\
\hline Vesper Sparrow & 5377 & 0.704 & 0.006 & 0.718 & 0.026 & 0.759 & 0.024 \\
\hline Western Meadowlark & 5662 & 0.763 & 0.005 & 0.883 & 0.025 & 0.814 & 0.024 \\
\hline
\end{tabular}

AUC: area under the curve

We also evaluated model sensitivity and specificity as measures of model performance. Species-specific thresholds that maximized the sum of model sensitivity and specificity (Liu et al. 2013), included as part of the MaxEnt modeling results, were used to convert the continuous predictions of climate suitability into binary predictions of suitable/unsuitable climate. We evaluated sensitivity as the proportion of test grid cells correctly predicted as suitable, and specificity as the proportion of background grid cells where the species was not observed ("pseudo-absences") that were correctly predicted as unsuitable. Threshold selection can have a large influence on the interpretation of modeled suitable climate and, therefore, the interpretation of distributional shifts in response to climate change (Nenzén and Araújo 2011), and there is little agreement on the best choice. However, the maximum sum of sensitivity and specificity threshold is well supported as a reasonable choice for presence-only models when evaluated against other methods across a range of prevalence values (Liu et al. 2005, 2013).

\section{Projected changes in breeding climate suitability in North America and Alberta}

Using the binary predictions of core suitable climate area from each GCM and the average predictions across GCMs, we calculated the projected changes in the area of suitable breeding climate between the baseline and future time periods in North America and Alberta for each species. Using these binary predictions, we also examined the climate stability of each species' current Alberta range by calculating the proportion of suitable climate area in the baseline period that was projected to remain suitable in each future time period.

\section{Projected breeding climate suitability correspondence} with current land cover in Alberta

We used the 2013 Annual Crop Inventory from Agriculture and Agri-Food Canada (AAFC) (AAFC 2013) to classify land cover in the agricultural region of Alberta (Fig. 1B; reclassification rules are presented in Appendix 2, Table A2.1). The AAFC data are generated at $30-\mathrm{m}$ resolution from satellite inventory, and distinguish between annual crop, native grassland, and tame pasture/hayland covers. We combined these latter two classes over concerns that they were not well differentiated (S. Davis, personal communication), so our "native/tame grassland" class contained all native and tame grassland and pasture land cover, including hay, and our "cropland" class was limited to annual row crops.

We defined suitable land cover for each species according to previously reported breeding habitat preferences (Table 1; rationales are presented in Appendix 1, Table A1.1). We examined changes in the degree of overlap between currently suitable land cover and the projected area of suitable climate by calculating the proportional change in area of suitable land cover within projected suitable climate, relative to the baseline prediction.

Current predictions and future projections were based on the average of the bootstrapped MaxEnt models for each species. Means, 95\% confidence intervals, and standard errors were based on the core areas projected by each of the four unique GCMs, and thus do not represent the full range of uncertainty represented by variability in replicated models. Projected future distribution maps, presented in Appendix 3, were based on the ensemble climate data. ArcGIS (v.10.1; ESRI) was used to process all species occurrence data and MaxEnt model outputs. Data summaries and figures were prepared in R (v.2.15.2) (R Core Team 2015).

\section{RESULTS}

\section{Model performance}

Averaged across all species, the climate variables with the highest rank importance were annual climate moisture index and mean summer precipitation (Table 2, Appendix 4). AUC values for the baseline climate models for 13 of 15 species were $\geq 0.7$ (Table 3 ). 
The other two species, Savannah Sparrow and Horned Lark, were among the species for which we had the greatest number of occupied cells relative to our background locations ( $52 \%$ and $34 \%$, respectively) (Table 3 ) (background $n=15,534$ ). The models for these two species and for Vesper Sparrow, another widely distributed species, also had relatively low sensitivity and specificity (Table 3 ). For all other species, both model sensitivity and specificity exceeded 0.75 , and for four species, both sensitivity and specificity exceeded 0.9 (Table 3 ). The binary maps generated using the maximum sum of specificity and sensitivity threshold for the baseline period (Appendix 3, Fig. A3.1) compared well with published North American range maps for most species (Poole 2005), indicating this threshold was a reasonable choice to reflect baseline suitable climate conditions.

\section{Projected changes in breeding climate suitability in North America}

End-of-century increases in suitable climate area in North America were projected for five of the 15 grassland songbird species (95\% CI did not include zero) (Appendix 5, Fig. A5.1). Horned Lark had the greatest predicted proportional expansion in suitable climate area $(55 \pm 14 \%$; mean $\pm 95 \% \mathrm{CI})$, followed by Lark Sparrow $(50 \pm 16 \%)$, Bobolink (42 $\pm 10 \%)$, Western Meadowlark (29 $\pm 19 \%)$, and Clay-colored Sparrow (19 $\pm 4 \%$ ). Three species were projected to experience reductions in suitable climate area in North America by the end of the century. McCown's Longspur had the largest projected proportional decline $(-83 \pm 7 \%)$, followed by Brewer's Sparrow (-57 $\pm 12 \%)$, and Savannah Sparrow $(-21 \pm 5 \%)$. The projected changes in suitable climate area in North America for the remaining seven species were more equivocal, with greater variability among GCMs relative to the magnitudes of change projected, and distribution changes rather than expansions or contractions projected in most cases.

In general, suitable climate area in North America for the 15 grassland songbird species was projected to shift northward, but the degree of shift was variable (Appendix 3, Fig. A3.1). For example, suitable climate area for the Chestnut-Collared Longspur and Lark Bunting was projected to shift gradually northward, while projected northward shifts in suitable climate area for Sprague's Pipit and Baird's Sparrow were more dramatic, especially by the end of the century (Appendix 3, Fig. A3.1). For other species, including Lark Sparrow and Horned Lark, suitable climate area was projected to expand to the north, with little change at the southern edge, resulting in an overall projected expansion across North America (Appendix 3, Fig. A3.1). Projected suitable climate area for Brewer's Sparrow and McCown's Longspur declined dramatically, with limited geographical shift (Appendix 3, Fig. A3.1).

\section{Projected changes in breeding climate suitability in Alberta}

Eight of 15 species were projected, on average, to experience increases in suitable climate area in Alberta by the end of the century (Fig. 2). The projected expansion for most species resulted from northward expansion of suitable climate area in Alberta, originating in the parkland region in northwest Alberta (e.g., Chestnut-collared Longspur, Lark Bunting, Lark Sparrow, Grasshopper Sparrow), with no or limited change in southern areas of the province (Appendix 3, Fig. A3.2). The greatest increase was projected for Bobolink, with an atypical pattern of suitable climate expansion from east to west across the province (Appendix 3, Fig. A3.2). Lark Sparrow and Grasshopper Sparrow were also both projected to show a many hundred-fold increase in suitable climate area in Alberta by the end of the century.

Five species were projected to experience end-of-century declines in suitable climate area in Alberta (Fig. 2). Three of these species, Savannah Sparrow (-24 $\pm 10 \%$; mean $\pm 95 \%$ CI), Clay-colored Sparrow (-26 $\pm 15 \%)$, and Le Conte's Sparrow (-48 $\pm 29 \%$ ), were species with widespread suitable climate areas in Alberta in the baseline period that shifted northward and out of Alberta over time. McCown's Longspur (-57 $\pm 29 \%)$ and Brewer's Sparrow (-57 $\pm 40 \%$ ) were projected to experience a decline in suitable climate area in Alberta that corresponded to a decline rather than a shift in suitable climate area across North America (Appendix 3, Fig. A3.2). Projected changes in suitable climate area in Alberta for Baird's Sparrow and Sprague's Pipit were more equivocal $(95 \%$ CI included zero), with greater variability among GCMs relative to the change projected (Fig. 2). However, both species were projected to experience northward shifts of both the northern and southern distribution limits of suitable climate (Appendix 3, Fig. A3.2).

There was considerable variation within species in the magnitude of change in suitable climate area among the projections from the four GCMs. For 11 of 15 species, however, the direction of change at the end of the century was consistent, regardless of GCM (Fig. 2). Individual climate model projections varied for Baird's Sparrow, Brewer's Sparrow, Chestnut-collared Longspur, and Sprague's Pipit. Of the four models, the warmest and driest scenarios represented by the United Kingdom model (UKMOHadGEM1; hotter and drier) and the American model (GFDLCM2.1; drier) generated larger increases or decreases in suitable climate area compared to the other three models and the ensemble projection.

\section{Stability of projected suitable breeding climate in Alberta}

By the end of the century, most species were projected to experience declines in the area of stable suitable climate, although nine species were, on average, projected to maintain at least $50 \%$ of their baseline suitable climate area (Fig. 3). The species projected to maintain the most stable climate area over time were those with limited losses of suitable climate area in southern Alberta (e.g., Horned Lark, Lark Bunting, Lark Sparrow, and Western Meadowlark), or with limited areas of suitable climate predicted in the baseline period (Bobolink) (Fig. 3). By the end of the century, the three species with the smallest projected areas of stable climate were Baird's Sparrow ( $7 \pm 3 \%$ ), Brewer's Sparrow $(8 \pm 3 \%)$, and Sprague's Pipit $(23 \pm 10 \%)$.

\section{Projected suitable breeding climate and current land cover in Alberta}

In Alberta, six of 15 species were projected to experience increases in suitable land cover within projected suitable climate: Bobolink, Grasshopper Sparrow, Horned Lark, Lark Bunting, Lark Sparrow, and Western Meadowlark (Fig. 4). The projected distributions of these six species occupied increasingly large areas 
Fig. 2. Projected change in the area of suitable climate in Alberta, Canada from the historical baseline (1961-1990) for two future time periods, based on North American models. The mean change ( $\pm 95 \%$ CI [black circles]) was determined from the four unique global climate models (GCMs) (CCCMA CGCM3.1; MPI ECHAM5/MPI-OM; GFDL CM2.1; UKMO-HadGEM1 [open symbols]). Changes in areas projected using the ensemble climate data (yellow squares) correspond to the maps in Figure A3.2. Note the difference in scales between panels.
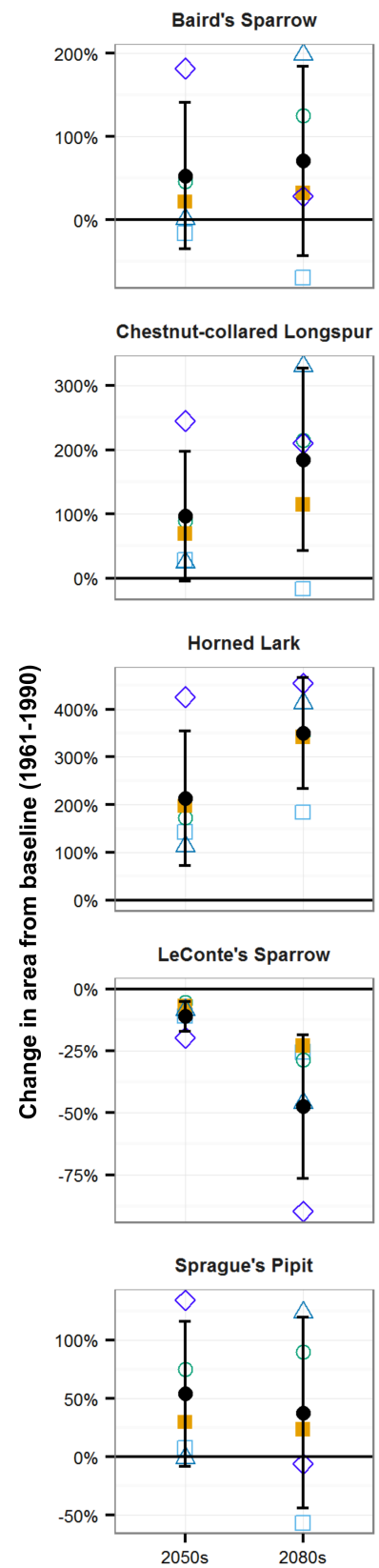
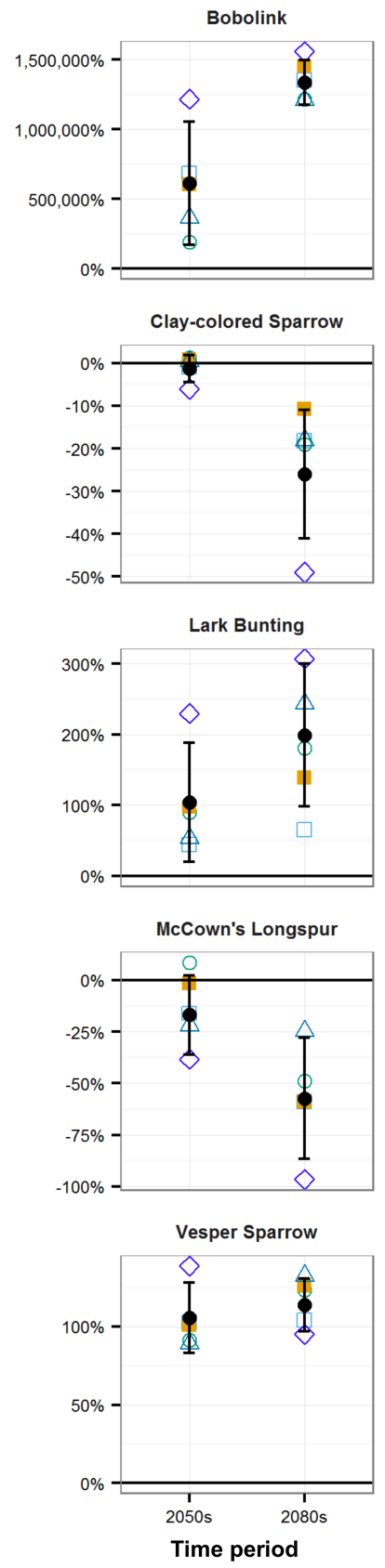
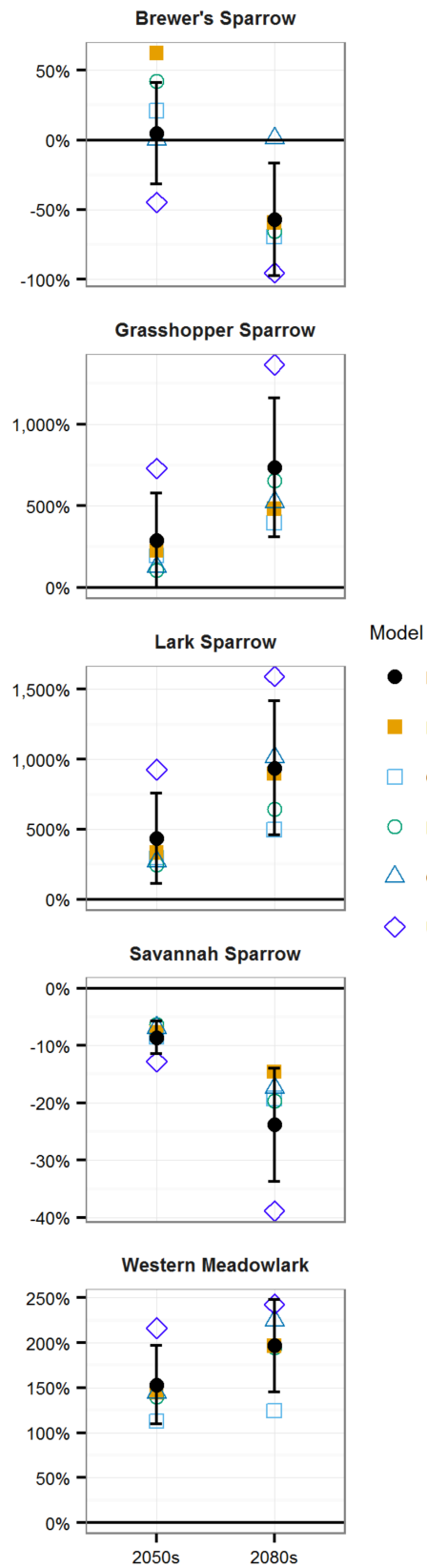

of potentially suitable land cover in the province (Fig. 1B; Fig. 2; Appendix 3, Fig. A3.2). Although Chestnut-collared Longspur was projected to experience an expansion in suitable climate area in Alberta (Fig. 2), the expansion did not overlap the distribution of suitable land cover, resulting in a relatively stable projection for the correspondence between suitable land cover and suitable climate over time (although variation among models was large) (Fig. 4A).

Several species with localized distributions that occupy native and tame pasture but not cropland, including Sprague's Pipit, Baird's Sparrow, Brewer's Sparrow, and McCown's Longspur, were projected to experience declines in suitable land cover within their 
Fig. 3. Percent of baseline (1961-1990) suitable climate projected to remain suitable in future time periods in Alberta, Canada based on North American models. The mean percent area $( \pm 95 \% \mathrm{CI})$ was determined from the four unique global climate models. Symbols as in Fig. 2.
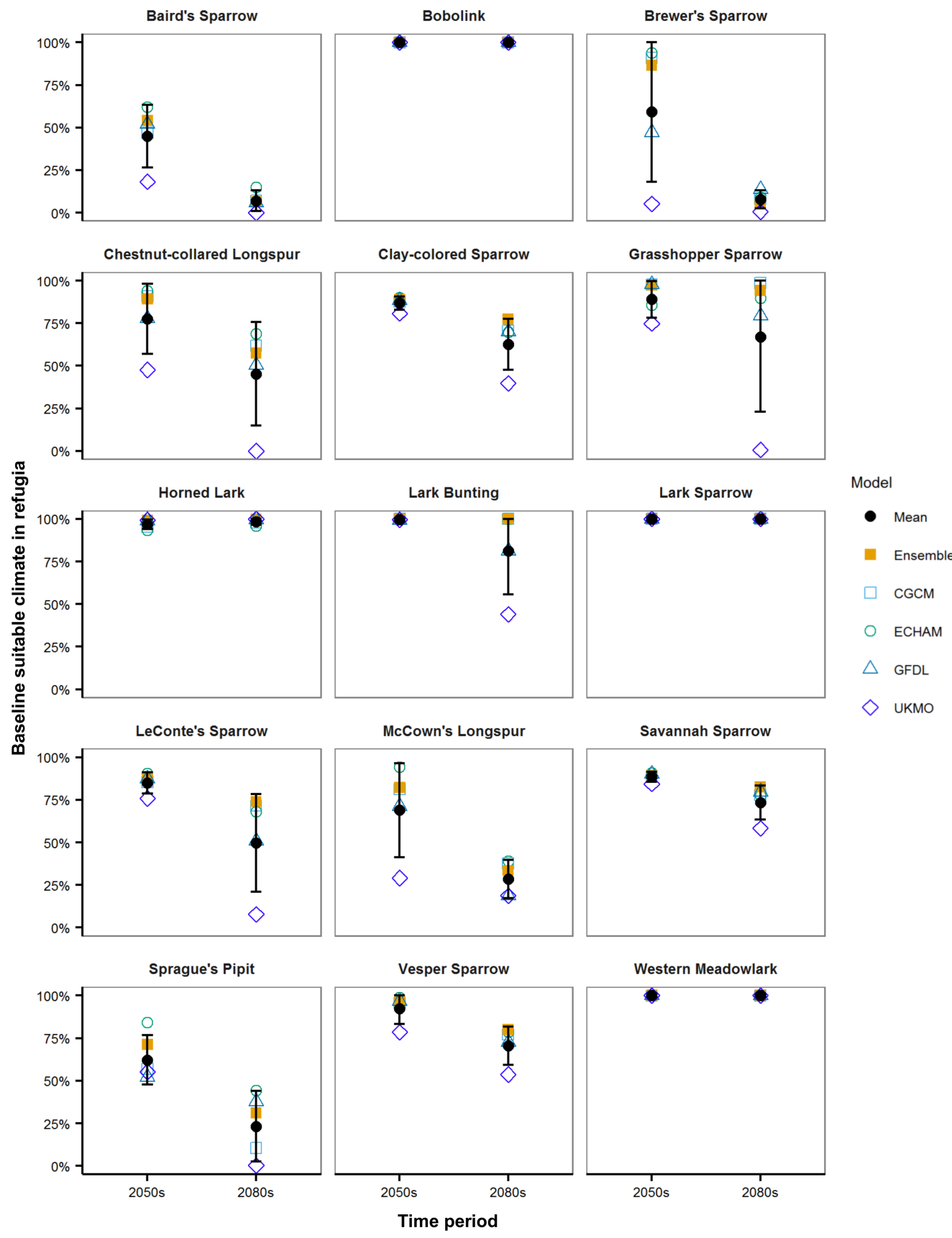

projected suitable climate (up to $-82 \pm 8 \%$ for Baird's Sparrow) (Fig. 4A). For McCown's Longspur and Brewer's Sparrow, this suitable land cover area corresponded to $35 \pm 14 \%$ and $42 \pm 11 \%$ of their projected suitable climate areas in Alberta at the end of the century, respectively, which reflected the relatively spatially stable but shrinking areas of suitable climate in Alberta for these species. In contrast, for Baird's Sparrow and Sprague's Pipit, this suitable land cover area corresponded to only $6 \pm 2 \%$ and $7 \pm 3 \%$ of their respective projected areas of suitable climate at the end of the century, respectively, which reflected the northward shift in suitable climate for both species into regions of the province that are dominated by unsuitable land cover, including cropland and forest (Appendix 3, Fig. A3.2).

Four generalist grassland songbirds were also projected to experience declines in suitable land cover within their projected suitable climates, regardless of whether they occupied cropland 
Fig. 4. Projected change in area of currently suitable land cover within suitable climate from the historical baseline (1961-1990) for two future time periods in Alberta, Canada. The mean change ( $\pm 95 \% \mathrm{CI})$ was determined from the four unique global climate models. Symbols as in Fig. 2. Species are separated according to use of land cover types for breeding: (A) 12 species that use both native and tame pasture and hayland, and (B) three species that additionally use cropland (Table 1). Note the difference in scales between panels.

A
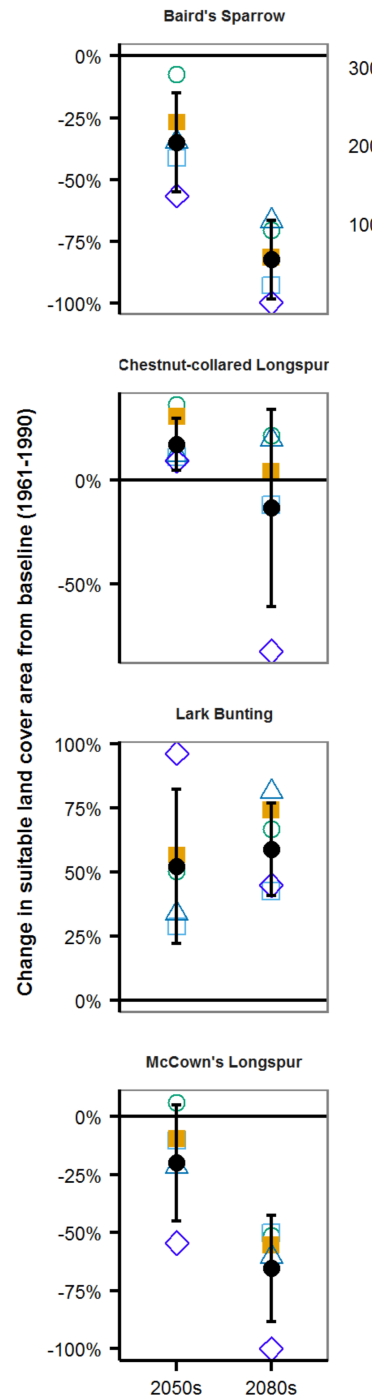
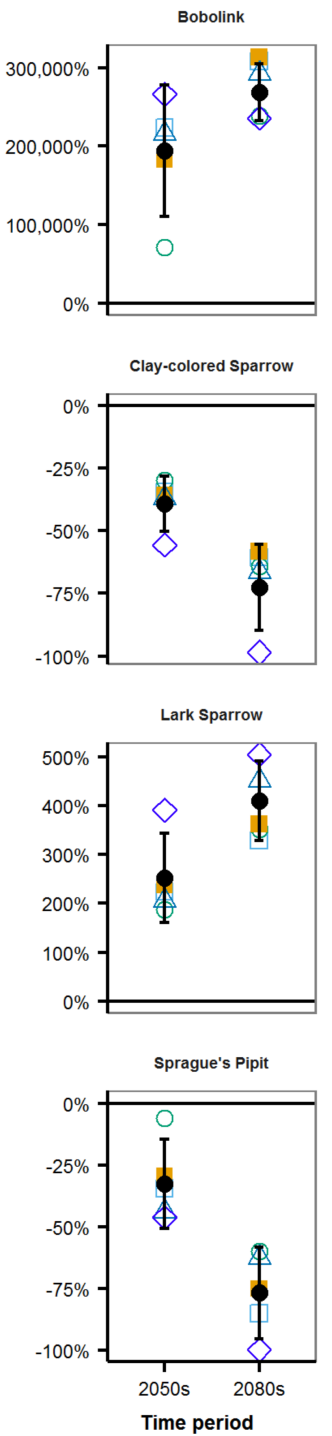

B
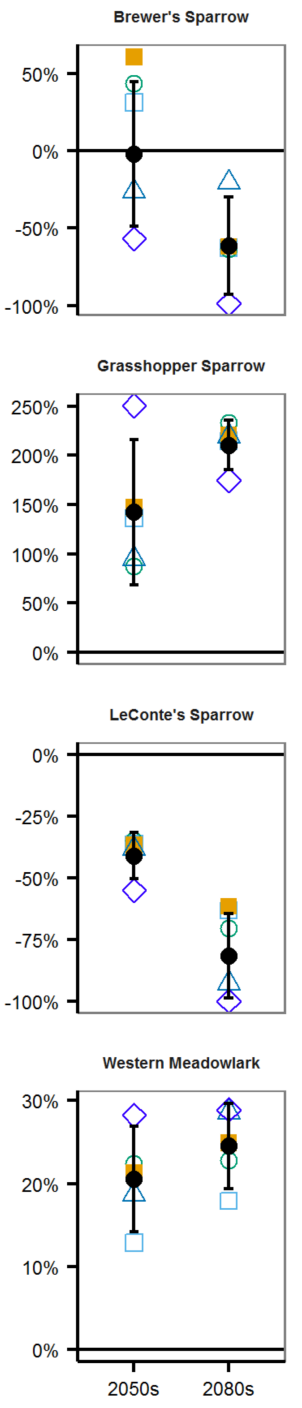
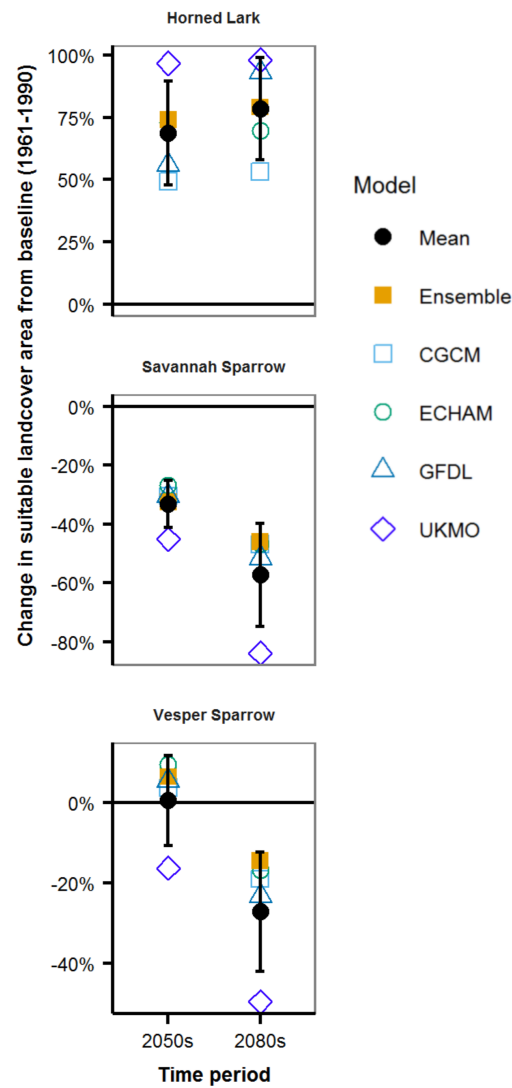

(Savannah Sparrow and Vesper Sparrow) (Fig. 4B) or not (Le Conte's Sparrow and Clay-colored Sparrow) (Fig. 4A). For all four species, these declines reflected northward shifts in suitable climate into the forested regions of Alberta where neither cropland nor native or tame pasture land covers currently exist (Fig. 1; Appendix 3, Fig. A3.2), and for all but Vesper Sparrow, reflected the overall projected decline in suitable climate area in the province.

\section{DISCUSSION}

Based on climate model projections of substantially warmer conditions over the next century, we projected northward expansions in suitable breeding climate for more than $50 \%$ of grassland songbird species that breed in the North American Great Plains region. These projected expansions were due in large part to increased climate suitability within Alberta and other Canadian prairie provinces, which confirms the importance of these areas as climate refugia for grassland birds. For generalist species that can take advantage of existing agricultural landscapes and grassland patches outside their current breeding range, our land cover inventory within Alberta suggested that these expansions may be manifest fairly readily. For species with more specialized habitat requirements, however, our analysis suggested that the projected increase in climate suitability would not be accompanied by suitable vegetation for nesting due to lags in the 
transition of native grassland vegetation communities. For the one-third of species that were projected to experience decreases in suitable climate area within Alberta, we found that grassland specialists were especially vulnerable to vegetation lags, given the loss of southern habitats.

\section{Land cover constraints on future suitable habitat for grassland songbirds}

The potential for grassland songbirds to occupy areas of projected suitable climate depends on a variety of factors. In addition to intrinsic species' characteristics like site fidelity and dispersal ability, and external factors such as prey availability (Wiens et al. 2009, Skagen and Adams 2012), the rate at which boreal and parkland vegetation transitions to grassland along the grasslandboreal ecotone will impact future grassland songbird distributions. Species that are reliant on native grasslands may be especially constrained by this limitation, being less able to capitalize on potential agricultural expansion. However, predicting ecosystem transition rates and vegetation distributions is complicated by disturbance and successional dynamics, grass species' dispersal, and edaphic constraints (e.g., Schneider et al. 2009).

Vegetation models that combine climate projections with future natural disturbance estimates suggest that native grassland ecosystems have the potential to move into much of the parkland region in Alberta by mid-century (Schneider et al. 2009, Stralberg et al. 2016), especially considering that drought-tolerant grasses already exist in small patches and on drier, south-facing slopes in the region (Natural Regions Committee 2006, Schneider 2013). However, land use in this region is largely agricultural (Fig. 1B), with existing vegetation communities increasingly dominated by non-native agronomic species (e.g., timothy [Phleum pretense] and smooth brome [Bromus inermis]) (Government of Alberta 2013). Given the persistence of these non-native species (Christian and Wilson 1999), opportunities for native grassland expansion by natural dispersal may be limited. Over longer time frames (e.g., end of century), similar expansion into the boreal region may be supported by scattered grasslands within that region (Schneider 2013), yet an absence of dry-adapted grasses, competition with sown non-native grasses along roadsides, and other disturbances will likely limit native grassland expansion (Sumners and Archibold 2007, Schneider 2013).

The warming and drying that is predicted to push grasslandassociated climates and vegetation into Alberta's parkland and boreal regions will also likely drive native grassland plant communities from the Great Plains of the United States into Alberta (Thorpe 2011, Schneider 2013). Predicted changes in native grassland composition and structure include a transition from mid to short grasses and potential changes in productivity (Sauchyn and Kulshreshtha 2008, Thorpe 2011), which may alter native grassland suitability for some songbird species. For example, increases in short grasses may reduce suitability for species like Sprague's Pipit that prefer taller and denser vegetation (Fisher and Davis 2011). Conversely, habitat suitability may increase for other species, like the Grasshopper Sparrow, that prefer nesting in short and sparse vegetation (Dechant et al. 2002).

For grassland songbirds that occupy pasture or cropland in addition to native grasslands, the future availability of suitable land cover will also depend on changes in agricultural land use in response to climate change. This includes potential transitions from crop cultivation to perennial agricultural cover, like hay, and potential northward expansion of agricultural activity into the boreal region, where it is currently limited (Thorpe 2011). For some species, however, with projected northward expansion but for which the value of tame pasture for their conservation is unclear (e.g., Chestnut-collared Longspur and Baird's Sparrow), preservation of native grassland at the northern extent of the current grassland ecoregion may become increasingly important for supporting their populations (Dale et al. 1997, Lloyd and Martin 2005, COSEWIC 2012). Understanding the value of new native grasslands outside the current grassland ecoregions for these species remains an avenue for future research.

\section{Regions of climate stability and climate change resilience}

Given the complexity and uncertainty associated with projecting future distributions of vegetation and land use, areas with relatively stable climate suitability will be particularly important for species persistence as climate change progresses. Our model projections suggest that most of the currently suitable climate for most grassland songbirds in Alberta will remain suitable over the next century, which highlights the importance of these regions for the long-term persistence of grassland songbirds. These areas are likely to maintain relatively stable vegetation communities in the absence of land use change (Ashcroft 2010), and will likely retain populations of grassland songbirds that could act as reservoirs to support range expansions if suitable habitat is restored. Species with small areas of projected climate stability in their current ranges will be more heavily dependent on shifting their distributions into areas with suitable land cover.

For two species of conservation concern in Canada and Alberta, Sprague's Pipit and Baird's Sparrow, our models projected large northward shifts in the distribution of suitable climate, with only small core areas of stable climate remaining. Because they are species of concern with small population sizes, they may be among the species least capable of expanding into newly suitable areas, as their current potential climatic niches are less likely to be fully occupied (Wiens et al. 2009). Furthermore, the more specific habitat requirements of these northern prairie-endemic species and the limited projected overlap of future areas of suitable climate with currently suitable land cover also suggests that the future distributions of these species will rely heavily on the successful transition of parkland and boreal vegetation to grassland vegetation. To the extent that the appearance of newly suitable habitat lags behind climatic shifts, the shifts in suitable climate area projected for these species could exacerbate recent population declines (COSEWIC 2010, 2012).

\section{Limitations and uncertainty}

We limited our analysis of land cover suitability to two broad categories of land cover within the agricultural region in Alberta. This definition of suitable land cover may have underestimated total suitable land cover in the province for widespread species, like Savannah Sparrow and Le Conte's Sparrow, that occupy grassland patches and other unforested habitats in the boreal region (Lowther 2005, Wheelwright and Rising 2008). Furthermore, grassland songbird habitat selection is certainly more complex than the distinction between pasture and annual 
cropland: some species differentially occupy pastures in response to grazing intensity and vegetation structure (e.g., Chestnutcollared Longspur) (COSEWIC 2009), or select habitat based on land use (e.g., hay versus pasture; Clay-colored Sparrow) (McMaster and Davis 2001). Provincial- or national-scale land cover data that reliably distinguish between native grasslands, tame pastures, and hay are not currently available; however, our approach represents a first step toward understanding how interactions between land cover and climate suitability may limit or facilitate grassland songbird distribution changes.

Using bioclimatic niche models to describe the potential impacts of climate change on species distributions is subject to a set of assumptions, particularly that (1) climate variables are an important predictor of species' distributions, and (2) species' distributions are at equilibrium with current climate conditions (Araújo and Peterson 2012). While climate has been found to be an important predictor of avian distributions (Araújo et al. 2009, Cumming et al. 2014), the inclusion of land use and land cover variables in species distribution models can refine projections of future suitable ranges, especially for species that show strong associations with certain land cover or land use types (BarbetMassin et al. 2012, Sohl 2014, Stralberg et al. 2015a). However, because future projections of land use change in the Great Plains and Boreal regions are currently unavailable, this remains an area for further research.

The assumption that species distributions and climatic niches are in equilibrium can be particularly problematic for declining species, like many of the grassland songbirds we examined, because their potential climatic niches are less likely to be fully occupied (Araújo and Pearson 2005, Wiens et al. 2009). Despite our use of a broad spatial and temporal data set in model calibration (Araújo and Peterson 2012), our models may have been prone to omission errors that would have underestimated the area of suitable climate in North America (Wiens et al. 2009). Additionally, most species observations in the modeling data set were from after 1980, and were temporally mismatched to the baseline climate data (1961-1990). In using these data sets, we have assumed that any recently observed climate change has been more rapid than the songbirds' response. Consequently, our projections may have also underestimated changes in the distribution of suitable climate for some species.

The interpretation of bioclimatic niche models is also subject to various sources of uncertainty independent of model assumptions, including uncertainty in the data, the choice of modeling algorithm, the selection of climate and other predictor variables, and the set of global climate models used to generate future projections (Wiens et al. 2009). Of these, uncertainty associated with global climate model selection was identified as the greatest contributor to variation in model projections for boreal songbirds (Stralberg et al. 2015a). For most of the species we examined, the direction of change in area of suitable climate by the end of the century was consistent among all global climate models.

Comparisons among outcomes from alternative modeling frameworks can help identify areas of consensus and areas for further work. For example, for species identified by Langham et al. (2015) as having ranges with limited projected climate stability and limited potential for range expansion in North America, we similarly identified limited climate stability and declines in suitable climate area at their northern range limits in Alberta, thereby providing support at a regional level for the continental assessment. Similarly, Langham et al. (2015) classified six of our 15 species as stable, and for all but one, we also projected large areas of climate stability (over $70 \%$ of the baseline area) in Alberta. For the species we examined that were identified by Langham et al. (2015) as having an anticipated reliance on range expansions for persistence, we projected only one to experience increasing areas of suitable climate overlap with suitable land cover in Alberta, which indicates the importance of considering potential land cover constraints in the evaluation of risk associated with projected range shifts.

\section{CONCLUSION}

Our approach represents another step toward understanding the potential consequences of climate change for grassland songbirds, including the potential for range expansion at their northern range edges. While uncertainty remains around the precise magnitudes and rates of change in suitable climate area and land cover, our projections suggest that some climate-mediated range expansion into areas of suitable land cover in Alberta is possible for many species. However, species with specialized habitat requirements and large projected changes in the distribution of suitable climate (Baird's Sparrow and Sprague's Pipit), and species with dramatic projected reductions in suitable climate area at both a continental and regional scale with limited climate stability (Brewer's Sparrow and McCown's Longspur) are likely very vulnerable to climate change. In the context of declining grassland songbird populations across North America, improved understanding of the potential consequences of interactions between climate change and land cover can support long-term conservation planning and management for these species. In particular, preservation and restoration of suitable grassland habitats within areas of projected climate stability along northern range edges could enhance the likelihood of long-term persistence of grassland songbirds within their current ranges. Additionally, planning to support potential range expansions, including restoration or creation of native grassland habitats outside the current grassland ecoregion, will become increasingly important to address climate change-related risks for some species.

Responses to this article can be read online at: http://www.ace-eco.org/issues/responses.php/866

\section{Acknowledgments:}

This research was conducted as part of the Biodiversity Management and Climate Change Adaptation project led by the Alberta Biodiversity Monitoring Institute with funding provided by the Climate Change and Emissions Management Corporation. We are grateful to Stephen Davis for contributing data and providing insightful comments on an earlier draft. The comments of two anonymous reviewers contributed greatly to improving the manuscript. We acknowledge the contributions of hundreds of skilled volunteers who have participated in the Breeding Bird Survey over the years, and the individuals who have contributed their avian survey data to the eBird database. Natural Sciences and Engineering Research Council of Canada provided financial support to RJF and DS. DS was also supported by a McAfee Estate Scholarship in 
Zoology through the Department of Biological Sciences at the University of Alberta.

\section{LITERATURE CITED}

Agriculture and Agri-Food Canada (AAFC). 2013. AAFC annual crop inventory. Government of Canada, Ottawa, Ontario, Canada. [online] URL: http://open.canada.ca/data/en/dataset/ ba2645d5-4458-414d-b196-6303ac06c1c9

Araújo, M. B., and R. G. Pearson. 2005. Equilibrium of species' distributions with climate. Ecography 28:693-695. http://dx.doi. org/10.1111/j.2005.0906-7590.04253.X

Araújo, M. B., and A. T. Peterson. 2012. Uses and misuses of bioclimatic envelope modeling. Ecology 93:1527-1539. http://dx. doi.org/10.1890/11-1930.1

Araújo, M. B., W. Thuiller, and N. G. Yoccoz. 2009. Reopening the climate envelope reveals macroscale associations with climate in European birds. Proceedings of the National Academy of Sciences of the United States of America 106:E45-E46. http://dx. doi.org/10.1073/pnas.0813294106

Ashcroft, M. B. 2010. Identifying refugia from climate change. Journal of Biogeography 37:1407-1413. http://dx.doi.org/10.1111/ j.1365-2699.2010.02300.x

Askins, R. A., F. Chávez-Ramírez, B. C. Dale, C. A. Haas, J. R. Herkert, F. L. Knopf, and P. D. Vickery. 2007. Conservation of grassland birds in North America: understanding ecological processes in different regions. Ornithological Monographs 64:146.

Barbet-Massin, M., W. Thuiller, and F. Jiguet. 2012. The fate of European breeding birds under climate, land-use and dispersal scenarios. Global Change Biology 18:881-890. http://dx.doi. org/10.1111/j.1365-2486.2011.02552.x

Christian, J. M., and S. D. Wilson. 1999. Long-term ecosystem impacts of an introduced grass in the northern Great Plains. Ecology 80:2397-2407. http://dx.doi.org/10.1890/0012-9658 (1999)080[2397:LTEIOA]2.0.CO;2

Commission for Environmental Cooperation (CEC). 1997. Ecological regions of North America: toward a common perspective. Montreal, Quebec, Canada. [online] URL: http:// www3.cec.org/islandora/en/item/1701-ecological-regions-north-americatoward-common-perspective-en.pdf

Committee on the Status of Endangered Wildlife in Canada (COSEWIC). 2012. COSEWIC assessment and status report on the Baird's Sparrow (Ammodramus bairdii) in Canada. Ottawa, Ontario, Canada. [online] URL: http://www.registrelepsararegistry.gc.ca/virtual_sara/files/cosewic/sr_bruant_baird_sparrow_1012_e.pdf

Committee on the Status of Endangered Wildlife in Canada (COSEWIC). 2010. COSEWIC assessment and status report on the Sprague's Pipit (Anthus spragueii) in Canada. Ottawa, Ontario, Canada. [online] URL: http://www.registrelepsararegistry.gc.ca/virtual_sara/files/cosewic/sr_Sprague $\% 27 \mathrm{~s} \%$ 20Pipit_0810_e.pdf

Committee on the Status of Endangered Wildlife in Canada (COSEWIC). 2009. COSEWIC assessment and status report on the Chestnut-collared Longspur (Calcarius ornatus) in Canada. Ottawa, Ontario, Canada. [online] URL: http://www.registrelepsararegistry.gc.ca/virtual_sara/files/cosewic/sr_Chestnut-collared $\%$ 20Longspur_0810_e1.pdf

Coristine, L. E., and J. T. Kerr. 2015. Temperature-related geographical shifts among passerines: contrasting processes along poleward and equatorward range margins. Ecology and Evolution 5:5162-5176. http://dx.doi.org/10.1002/ece3.1683

Cumming, S. G., D. Stralberg, K. L. Lefevre, P. Sólymos, E. M. Bayne, S. Fang, T. Fontaine, D. Mazerolle, F. K. A. Schmiegelow, and S. J. Song. 2014. Climate and vegetation hierarchically structure patterns of songbird distribution in the Canadian boreal region. Ecography 37:137-151. http://dx.doi.org/10.1111/ j.1600-0587.2013.00299.x

Dale, B. C., P. A Martin, and P. S. Taylor. 1997. Effects of hay management on grassland songbirds in Saskatchewan. Wildlife Society Bulletin 25:616-626.

Daly, C., M. Halbleib, J. I. Smith, W. P. Gibson, M. K. Doggett, G. H. Taylor, J. Curtis, and P. P. Pasteris. 2008. Physiographically sensitive mapping of climatological temperature and precipitation across the conterminous United States. International Journal of Climatology 28:2031-2064. http://dx.doi. org/10.1002/joc. 1688

Davis, S. K., R. J. Fisher, S. L. Skinner, T. L. Shaffer, and R. M. Brigham. 2013. Songbird abundance in native and planted grassland varies with type and amount of grassland in the surrounding landscape. Journal of Wildlife Management 77:908919. http://dx.doi.org/10.1002/jwmg.537

Davis, S. K., M. B. Robbins, and B. C. Dale. 2014. Sprague's Pipit (Anthus spragueii). In A. Poole, editor. The Birds of North America Online. Cornell Lab of Ornithology, Ithaca, New York, USA. [online] URL: http://bna.birds.cornell.edu/bna/species/439

Dechant, J. A., M. L. Sondreal, D. H. Johnson, L. D. Igl, C. M. Goldade, M. P. Nenneman, and B. R. Euliss. 2002. Effects of management practices on grassland birds: Grasshopper Sparrow. Northern Prairie Wildlife Research Center, Jamestown, North Dakota, USA. [online] URL: https://pubs.er.usgs.gov/publication/93877

Dormann, C. F., J. Elith, S. Bacher, C. Buchmann, G. Carl, G. Carré, J. R. García Marquéz, B. Gruber, B. Lafourcade, P. J. Leitão, T. Münkemüller, C. McClean, P. E. Osborne, B. Reineking, B. Schröder, A. K. Skidmore, D. Zurell, and S. Lautenbach. 2012. Collinearity: a review of methods to deal with it and a simulation study evaluating their performance. Ecography 35:001-020.

Elith, J., S. J. Philips, T. Hastie, M. Dudík, Y. E. Chee, and C. J. Yates. 2011. A statistical explanation of MaxEnt for ecologists. Diversity and Distributions 17:43-57. http://dx.doi.org/10.1111/ j.1472-4642.2010.00725.x

Fielding, A. H., and J. F. Bell. 1997. A review of methods for the assessment of prediction errors in conservation presence/absence models. Environmental Conservation 24:38-49. http://dx.doi. org/10.1017/S0376892997000088

Fisher, R. J. and S. K. Davis. 2011. Habitat use by Sprague's pipits (Anthus spragueii) in native pastures and planted, non-native hay fields. Auk 128:273-282. http://dx.doi.org/10.1525/auk.2011.10148 
Friedlingstein, P., R. M. Andrew, G. P. Peters, J. G. Canadell, R. Knutti, G. Luderer, M. R. Raupach, M. Schaeffer, D. P. van Vuuren, and C. Le Quéré. 2014. Persistent growth of $\mathrm{CO}_{2}$ emissions and implications for reaching climate targets. Nature Geoscience 7:709-715. http://dx.doi.org/10.1038/ngeo2248

Government of Alberta. 2013. Central parkland range plant community guide. Publication No. T/265. Red Deer, Alberta, Canada. [online] URL: http://open.alberta.ca/dataset/ dd6057fd-7355-4a9d-b3d7-6908775650b2/resource/e5453bfbe211-47ca-91cd-4f8039786093/download/2013-CentralParklandRangePlantGuide.pdf

Hitch, A. T., and P. L. Leberg. 2007. Breeding distributions of North American bird species moving north as a result of climate change. Conservation Biology 21:534-539. http://dx.doi. org/10.1111/j.1523-1739.2006.00609.x

Hogg, E. H. 1997. Temporal scaling of moisture and the forestgrassland boundary in western Canada. Agricultural and Forest Meteorology 84:115-122. http://dx.doi.org/10.1016/S0168-1923 (96)02380-5

Intergovernmental Panel on Climate Change (IPCC). 2001. Climate change 2001: the scientific basis. Contribution of Working Group I to the Third Assessment Report of the Intergovernmental Panel on Climate Change. Cambridge University Press, Cambridge.

Knopf, F. L. 1994. Avian assemblages on altered grasslands. Studies in Avian Biology 15:247-257.

Langham, G. M., J. G. Schuetz, T. Distler, C. U. Soykan, and C. Wilsey. 2015. Conservation status of North American birds in the face of future climate change. PLoS ONE 10(9):e0135350. http:// dx.doi.org/10.1371/journal.pone. 0135350

Liu, C., P. M. Berry, T. P. Dawson, and R. G. Pearson. 2005. Selecting thresholds of occurrence in the prediction of species distributions. Ecography 28:385-393. http://dx.doi.org/10.1111/ j.0906-7590.2005.03957.x

Liu, C., M. White, and G. Newell. 2013. Selecting thresholds for the prediction of species occurrence with presence-only data. Journal of Biogeography 40:778-789. http://dx.doi.org/10.1111/ jbi. 12058

Lloyd, J. D., and T. E. Martin. 2005. Reproductive success of Chestnut-collared Longspurs in native and exotic grassland. Condor 107:363-374. http://dx.doi.org/10.1650/7701

Lobo, J. M., A. Jiménez-Valverde, and R. Real. 2008. AUC: a misleading measure of the performance of predictive distribution models. Global Ecology and Biogeography 17:145-151. http://dx. doi.org/10.1111/j.1466-8238.2007.00358.x

Lowther, P. E. 2005. Le Conte's Sparrow (Ammodramus leconteii). In A. Poole, editor. The Birds of North America Online. Cornell Lab of Ornithology, Ithaca, New York, USA. [online] URL: http://bna.birds.cornell.edu/bna/species/224

Manel, S., H. C. Williams, and S. J. Ormerod. 2001. Evaluating presence-absence models in ecology: the need to account for prevalence. Journal of Applied Ecology 38:921-931. http://dx.doi. org/10.1046/j.1365-2664.2001.00647.x
McMaster, D. G., and S. K. Davis. 2001. An evaluation of Canada's permanent cover program: habitat for grassland birds? Journal of Field Ornithology 72:195-210. http://dx.doi. org/10.1648/0273-8570-72.2.195

Meehl, G. A., C. Covey, K. E. Taylor, T. Delwroth, R. J. Souffer, M. Latif, B. McAvaney, and J. F. B. Mitchell. 2007. The WCRP CMIP3 multimodel dataset: a new era in climate change research. Bulletin of the American Meteorological Society 88:1383-1394. http://dx.doi.org/10.1175/BAMS-88-9-1383

Merow, C., M. J. Smith, and J. A. Silander, Jr. 2013. A practical guide to MaxEnt for modeling species' distributions: what it does, and why inputs and settings matter. Ecography 36:1058-1069. http://dx.doi.org/10.1111/j.1600-0587.2013.07872.x

Munson, M. A., K. Webb, D. Sheldon, D. Fink, W. M. Hochachka, M. Iliff, M. Riedewald, D. Sorokina, B. Sullivan, C. Wood, and S. Kelling. 2013. The eBird reference dataset, Version 5.0. Cornell Lab of Ornithology and National Audubon Society, Ithaca, New York, USA.

Natural Regions Committee. 2006. Natural regions and subregions of Alberta. Government of Alberta, Edmonton, Alberta, Canada. [online] URL: https://open.alberta.ca/dataset/ dd01aa27-2c64-46ca-bc93-ca7ab5a145a4/resource/98f6a93e-c629-46fca025-114d79a0250d/download/2006-nrsrcomplete-may.pdf

Nenzén, H. K., and M. B. Araújo. 2011. Choice of threshold alters projections of species range shifts under climate change. Ecological Modelling 222:3346-3354. http://dx.doi.org/10.1016/j. ecolmodel.2011.07.011

Niemuth, N. D., J. W. Solberg, and T. L. Shaffer. 2008. Influence of moisture on density and distribution of grassland birds in North Dakota. Condor 110:211-222. http://dx.doi.org/10.1525/ cond.2008.8514

North American Bird Conservation Initiative, U.S. Committee (NABCI). 2014. The state of the birds 2014: United States of America. U.S. Department of Interior, Washington, D.C., USA. [online] URL: http://www.stateofthebirds.org/2014/2014\%

20SotB_FINAL_low-res.pdf

Phillips, S. J., R. P. Anderson, and R. E. Schapire. 2006. Maximum entropy modeling of species geographic distributions. Ecological Modelling 190:231-259. http://dx.doi.org/10.1016/j.

ecolmodel.2005.03.026

Phillips, S. J., M. Dudík, J. Elith, C. H. Graham, A. Lehmann, J. Leathwick, and S. Ferrier. 2009. Sample selection bias and presence-only distribution models: implications for background and pseudo-absence data. Ecological Applications 19:181-197. http://dx.doi.org/10.1890/07-2153.1

Poole, A., editor. 2005. The Birds of North America Online. Cornell Laboratory of Ornithology, Ithaca, New York, USA. [online] URL: http://bna.birds.cornell.edu/BNA/

R Core Team. 2015. R: a language and environment for statistical computing. R Foundation for Statistical Computing, Vienna, Austria. [online] URL: http://www.R-project.org

Rehfeldt, G. E., N. L. Crookston, C. Sáenz-Romero, and E. M. Campbell. 2012. North American vegetation model for land-use planning in a changing climate: a solution to large classification 
problems. Ecological Applications 22:119-141. http://dx.doi. org/10.1890/11-0495.1

Rotenberry, J. T., and J. A. Wiens. 1991. Weather and reproductive variation in shrubsteppe sparrows: a hierarchical analysis. Ecology 72:1325-1335. http://dx.doi.org/10.2307/1941105

Sauchyn, D., and S. Kulshreshtha. 2008. Prairies. Pages 275-328 in D. S. Lemmen, F. J. Warren, J. Lacroix, and E. Bush, editors. From Impacts to adaptation: Canada in a changing climate 2007. Government of Canada, Ottawa, Ontario, Canada. [online] URL: http://www.nrcan.gc.ca/environment/resources/publications/ impacts-adaptation/reports/assessments/2008/10253

Sauer, J. R., J. E. Hines, J. E. Fallon, K. L. Pardieck, D. J. Ziolkowski, Jr., and W. A. Link. 2014. The North American Breeding Bird Survey, results and analysis 1966-2012. Version 02.19.2014. USGS Patuxent Wildlife Research Centre, Laurel, Maryland, USA. [online] URL: http://www.mbr-pwrc.usgs.gov/ bbs/bbs2012.html

Sauer, J. R, and W. A. Link. 2011. Analysis of the North American breeding bird survey using hierarchical models. Auk 128:87-98. http://dx.doi.org/10.1525/auk.2010.09220

Schneider, R. R. 2013. Alberta's Natural Subregions under a changing climate: past, present and future. Prepared for the Biodiversity Management and Climate Change Adaptation Project/Alberta Biodiversity Monitoring Institute, Edmonton, Alberta, Canada. [online] URL: http://ftp.public.abmi.ca//home/ publications/documents/291_Schneider_2013_AlbertaNaturalSubregionsUnderAChangingClimate_ABMI.pdf

Schneider, R. R., A. Hamann, D. Farr, X. Wang, and S. Boutin. 2009. Potential effects of climate change on ecosystem distribution in Alberta. Canadian Journal of Forest Research 39:1001-1010. http://dx.doi.org/10.1139/X09-033

Skagen, S. K., and A. A. Y. Adams. 2012. Weather effects on avian breeding performance and implications of climate change. Ecological Applications 22:1131-1145. http://dx.doi.org/10.1890/11-0291.1

Sohl, T. L. 2014. The relative impacts of climate and land-use change on conterminous United States bird species from 2001 to 2075. PLOS ONE 9:e112251. http://dx.doi.org/10.1371/journal. pone. 0112251

Staudt, A., A. K. Leidner, J. Howard, K. A. Brauman, J. S. Dukes, L. J. Hansen, C. Paukert, J. Sabo, and L. A. Solórzano. 2013. The added complications of climate change: understanding and managing biodiversity and ecosystems. Frontiers in Ecology and the Environment 11:494-501. http://dx.doi.org/10.1890/120275

Stralberg, D., E. M. Bayne, S. G. Cumming, P. Sólymos, S. J. Song, and F. K. A. Schmiegelow. 2015b. Conservation of future boreal forest bird communities considering lags in vegetation response to climate change: a modified refugia approach. Diversity and Distributions 21:1112-1128. http://dx.doi.org/10.1111/ddi.12356
Stralberg, D., S. M. Matsuoka, A. Hamann, E. M. Bayne, P. Sólymos, F. K. A. Schmiegelow, X. Wang, S. G. Cumming, and S. J. Song. 2015a. Projecting boreal bird responses to climate change: the signal exceeds the noise. Ecological Applications 25:52-69. http://dx.doi.org/10.1890/13-2289.1

Stralberg, D., X. Wang, M.-A. Parisien, F. N. Robinne, C. L. Mahon, P. Sólymos, and E. M. Bayne. 2016. Chapter 3 in Scenarios of future climate- and disturbance-driven changes for the boreal forest region of Alberta. Dissertation. University of Alberta, Edmonton, Alberta, Canada.

Sullivan, B. L., C. L. Wood, M. J. Iliff, R. E. Bonney, D. Fink, and S. Kelling. 2009. eBird: a citizen-based bird observation network in the biological sciences. Biological Conservation 142:2282-2292. http://dx.doi.org/10.1016/j.biocon.2009.05.006

Sumners, W. H., and O. W. Archibold. 2007. Exotic plant species in the southern boreal forest of Saskatchewan. Forest Ecology and Management 251:156-163. http://dx.doi.org/10.1016/j.foreco.2007.06.001

Thorpe, J. 2011. Vulnerability of prairie grasslands to climate change. Limited report prepared for Prairies Regional Adaptation Collaborative (PRAC). Saskatchewan Research Council, Saskatoon, Saskatchewan, Canada. SRC Publication No. 12855-2E11. [online] URL: http://www.parc.ca/rac/fileManagement/ upload/12855-2E11\%20Vulnerability $\% 20$ of $\% 20$ Grasslands $\% 20$ to $\%$ 20climate $\% 20$ change.pdf

Wang, T., A. Hamann, D. L. Spittlehouse, and T. Q. Murdoch. 2012. ClimateWNA - high-resolution spatial climate data for western North America. Journal of Applied Meteorology and Climatology 51:16-29. http://dx.doi.org/10.1175/JAMC-D-11-043.1

Wellicome, T. I., K. J. Kardynal, R. J. Franken, and C. S. Gillies. 2014. Off-road sampling reveals a different grassland bird community than roadside sampling: implications for survey design and estimates to guide conservation. Avian Conservation \& Ecology 9:4. http://dx.doi.org/10.5751/ACE-00624-090104

Wheelwright, N. T., and J. D. Rising. 2008. Savannah Sparrow (Passerculus sandwichensis). In A. Poole, editor. The Birds of North America Online. Cornell Lab of Ornithology, Ithaca, New York, USA. [online] URL: http://bna.birds.cornell.edu/bna/species/045

Wiens, J. A. 1974. Climatic instability and the "ecological saturation" of bird communities in North American grasslands. Condor 76:385-400. http://dx.doi.org/10.2307/1365813

Wiens, J. A., D. Stralberg, D. Jongsomijit, C. A. Howell, and M. A. Snyder. 2009. Niches, models, and climate change: assessing the assumptions and uncertainties. Proceedings of the National Academy of Sciences of the United States of America 106:1972919736. http://dx.doi.org/10.1073/pnas.0901639106

Zuckerberg, B., A. M. Woods, and W. F. Porter. 2009. Poleward shifts in breeding bird distributions in New York State. Global Change Biology 15:1866-1883. http://dx.doi.org/10.1111/ j.1365-2486.2009.01878.x
Editor-in-Chief: Ryan Norris

Subject Editor: Brad Fedy
Sponsored by the Society of Canadian Ornithologists and Bird Studies Canada Parrainée par la Société des ornithologistes du Canada et Etudes d'oiseaux Canada

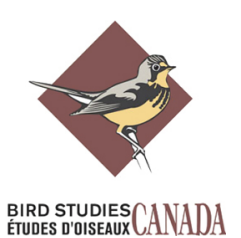


Table A1.1 continued (completed on next page).

\begin{tabular}{|c|c|c|c|}
\hline $\begin{array}{l}\text { Grasshopper } \\
\text { Sparrow }\end{array}$ & $\begin{array}{l}\text { Ammodramus } \\
\text { savannarum }\end{array}$ & $\mathrm{G}$ & $\begin{array}{l}\text { This species breeds in moderately open } \\
\text { grassland habitat and both native and tame } \\
\text { pastures are used. }{ }^{17,18} \text { It occasionally occupies } \\
\text { cropland, but at very low density. }{ }^{2,18}\end{array}$ \\
\hline Horned Lark & $\begin{array}{l}\text { Eremophila } \\
\text { alpestris }\end{array}$ & $\mathrm{G} / \mathrm{C}$ & $\begin{array}{l}\text { This species is common and widespread in open } \\
\text { habitats, especially with some bare ground and } \\
\text { short grasses, and frequently occupies cropland } \\
\text { habitats. }{ }^{2,14,19}\end{array}$ \\
\hline Lark Bunting & $\begin{array}{l}\text { Calamospiza } \\
\text { melanocorys }\end{array}$ & $\mathrm{G}$ & $\begin{array}{l}\text { This species occupies grassland and shrub- } \\
\text { steppe habitats, and breeds in native and tame } \\
\text { pastures and cultivated hayfields. }{ }^{20,21} \text { It } \\
\text { occasionally uses cropland but is much more } \\
\text { commonly found in tame pasture. } .^{21}\end{array}$ \\
\hline $\begin{array}{l}\text { Lark } \\
\text { Sparrow }\end{array}$ & $\begin{array}{l}\text { Chondestes } \\
\text { grammacus }\end{array}$ & $\mathrm{G}$ & $\begin{array}{l}\text { This species occupies structurally open habitats, } \\
\text { including native and tame vegetation, with a } \\
\text { preference for ecotones between grassland and } \\
\text { shrub or forested habitats. }{ }^{2,23} \text { Cropland use by } \\
\text { this species is uncommon because of the } \\
\text { absence of woody vegetation in cropland } \\
\text { habitat. }{ }^{22,23}\end{array}$ \\
\hline $\begin{array}{l}\text { Le Conte's } \\
\text { Sparrow }\end{array}$ & $\begin{array}{l}\text { Ammodramus } \\
\text { leconteii }\end{array}$ & $\mathrm{G}$ & $\begin{array}{l}\text { This species occupies open uplands and } \\
\text { lowlands, including in prairie and aspen } \\
\text { parkland. } .^{24} \text { It typically nests in hayland, tame } \\
\text { pasture or native vegetation and is generally not } \\
\text { detected in cropland. } .^{25}\end{array}$ \\
\hline $\begin{array}{l}\text { McCown's } \\
\text { Longspur }\end{array}$ & $\begin{array}{l}\text { Rhynchophanes } \\
\text { mccownii }\end{array}$ & $\mathrm{G}$ & $\begin{array}{l}\text { This species occupies native short-grass and } \\
\text { mixed-grass prairie and tame pasture. }{ }^{26,27} \\
\text { Cropland use has appeared since the } 1990 \text { s, but } \\
\text { is associated with low productivity and may be } \\
\text { an ecological trap. }{ }^{2,5,28}\end{array}$ \\
\hline $\begin{array}{l}\text { Savannah } \\
\text { Sparrow }\end{array}$ & $\begin{array}{l}\text { Passerculus } \\
\text { sandwichnesis }\end{array}$ & $\mathrm{G} / \mathrm{C}$ & $\begin{array}{l}\text { This species uses a variety of tame pasture and } \\
\text { native grassland habitats and successfully breeds } \\
\text { in cropland. } 5,29\end{array}$ \\
\hline $\begin{array}{l}\text { Sprague's } \\
\text { Pipit }\end{array}$ & $\begin{array}{l}\text { Anthus } \\
\text { spragueii }\end{array}$ & $\mathrm{G}$ & $\begin{array}{l}\text { This species is closely associated with grazed } \\
\text { native mixed-grass prairie in good condition. }{ }^{30} \mathrm{It} \\
\text { occurs and nests in low numbers in tame pasture } \\
\text { and is rarely recorded in cropland. } .^{30,31}\end{array}$ \\
\hline
\end{tabular}

${ }^{17}$ Vickery (1996), ${ }^{18}$ Dechant et al. (2002b), ${ }^{19}$ Beason (1995), ${ }^{20}$ Shane (2000), ${ }^{21}$ Dechant et al. (2002c), ${ }^{22}$ Dechant et al. (2003a), ${ }^{23}$ Martin and Parrish (2000), ${ }^{24}$ Lowther (2005), ${ }^{25}$ Dechant et al. (2003b), ${ }^{26}$ With (2010), ${ }^{27}$ Dechant et al. (2002d), ${ }^{28}$ COSEWIC (2006), ${ }^{29}$ Wheelwright and Rising (2008), ${ }^{30}$ Davis et al. (2014), ${ }^{31}$ COSEWIC (2010b). 
Table A1.1 completed.

\begin{tabular}{llll}
\hline $\begin{array}{l}\text { Vesper } \\
\text { Sparrow }\end{array}$ & $\begin{array}{l}\text { Pooecetes } \\
\text { gramineus }\end{array}$ & G/C & $\begin{array}{l}\text { This species occupies a broad range of grassland } \\
\text { habitat types, including native and tame pasture } \\
\text { and cultivated cropland. }{ }^{2,12,32}\end{array}$ \\
$\begin{array}{l}\text { Western } \\
\text { Meadowlark }\end{array}$ & $\begin{array}{l}\text { Sturnella } \\
\text { neglecta }\end{array}$ & $\mathrm{G}$ & $\begin{array}{l}\text { This species is most common in native } \\
\text { grasslands and perennial grassland cover and is } \\
\text { uncommon in cropland.,14,33 }\end{array}$ \\
\hline
\end{tabular}

32 Jones and Cornely (2002), ${ }^{33}$ Davis and Lanyon (2008).

\section{Literature Cited}

ABMI (Alberta Biodiversity Monitoring Institute). 2014. Brewer's Sparrow (Spizella breweri). ABMI Species Website, version 2.0. [online] URL: http://species.abmi.ca/content/birds/BrewersSparrow.html.

Beason, R. C. 1995. Horned Lark (Eremophila alpestris), The Birds of North America Online (A. Poole, Ed.). Ithaca: Cornell Lab of Ornithology. [online] URL: http://bna.birds.cornell.edu/bna/species/195

COSEWIC. 2012. COSEWIC assessment and status report on the Baird's Sparrow (Ammodramus bairdii) in Canada. Committee on the Status of Endangered Wildlife in Canada. Ottawa. $\mathrm{x}+32 \mathrm{pp}$.

COSEWIC. 2010a. COSEWIC assessment and status report on the Bobolink (Dolichonyx oryzivorus) in Canada. Committee on the Status of Endangered Wildlife in Canada. Ottawa. vi +42 pp.

COSEWIC. 2010b. COSEWIC assessment and status report on the Sprague's Pipit (Anthus spragueii) in Canada. Committee on the Status of Endangered Wildlife in Canada. Ottawa. vii $+28 \mathrm{pp}$.

COSEWIC. 2009. COSEWIC assessment and status report on the Chestnut-collared Longspur (Calcarius ornatus) in Canada. Committee on the Status of Endangered Wildlife in Canada. Ottawa. vi + $36 \mathrm{pp}$.

COSEWIC. 2006. COSEWIC assessment and status report on the McCown's Longspur (Calcarius mccownii) in Canada. Committee on the Status of Endangered Wildlife in Canada. Ottawa. vi+23 pp.

Davis, S. K., and W. E. Lanyon. 2008. Western Meadowlark (Sturnella neglecta), The Birds of North America Online (A. Poole, Ed.). Ithaca: Cornell Lab of Ornithology. [online] URL: http://bna.birds.cornell.edu/bna/species/104

Davis, S. K., and D. C. Duncan. 1999. Grassland songbird occurrence in native and crested wheatgrass pastures of southern Saskatchewan. Studies in Avian Biology 19:211-218.

Davis, S. K., M. B. Robbins, and B. C. Dale. 2014. Sprague's Pipit (Anthus spragueii), The Birds of North America Online (A. Poole, Ed.). Ithaca: Cornell Lab of Ornithology. [online] URL: http://bna.birds.cornell.edu/bna/species/439

Davis, S. K., D. C. Duncan, and M. Skeel. 1999. Distribution and habitat associations of three endemic grassland songbirds in southern Saskatchewan. The Wilson Bulletin 111:389-396. 
Dechant, J. A., M. L. Sondreal, D. H. Johnson, L. D. Igl, C. M. Goldade, B. D. Parkin, and B. R. Euliss. 2003a. Effects of management practices on grassland birds: Lark Sparrow. Northern Prairie Wildlife Research Center, Jamestown, ND. 18 pp.

Dechant, J. A., M. L. Sondreal, D. H. Johnson, L. D. Igl, C. M. Goldade, A. L. Zimmerman, and B. R. Euliss. 2003b. Effects of management practices on grassland birds: Le Conte's Sparrow. Northern Prairie Wildlife Research Centre, Jamestown, ND. 15 pp.

Dechant, J. A., M. L. Sondreal, D. H. Johnson, L. D. Igl, C. M. Goldade, M. P. Nenneman, and B. R. Euliss. 2002a. Effects of management practices on grassland birds: Clay-colored Sparrow. Northern Prairie Wildlife Research Center, Jamestown, ND. 22 pp.

Dechant, J. A., M. L. Sondreal, D. H. Johnson, L. D. Igl, C. M. Goldade, M. P. Nenneman, and B. R. Euliss. 2002b. Effects of management practices on grassland birds: Grasshopper Sparrow. Northern Prairie Wildlife Research Center, Jamestown, ND. 28 pp.

Dechant, J. A., M. L. Sondreal, D. H. Johnson, L. D. Igl, C. M. Goldade, A. L. Zimmerman, and B. R. Euliss. 2002c. Effects of management practices on grassland birds: Lark Bunting. Northern Prairie Wildlife Research Center, Jamestown, ND. 18 pp.

Dechant, J. A., M. L. Sondreal, D. H. Johnson, L. D. Igl, C. M. Goldade, P. A. Rabie, and B. R. Euliss. 2002d. Effects of management practices on grassland birds: McCown's Longspur. Northern Prairie Wildlife Research Center, Jamestown, ND. 13 pp.

Grant, T. A., and R. W. Knapton. 2012. Clay-colored Sparrow (Spizella pallida), The Birds of North America Online (A. Poole, Ed.). Ithaca: Cornell Lab of Ornithology. [online] URL: http://bna.birds.cornell.edu/bna/species/120

Green, M. T., P. E. Lowther, S. L. Jones, S. K. Davis, and B. C. Dale. 2002. Baird's Sparrow (Ammodramus bairdii), The Birds of North America Online (A. Poole, Ed.). Ithaca: Cornell Lab of Ornithology. [online] URL: http://bna.birds.cornell.edu/bna/species/638

Hill, D. P,. and L. K. Gould. 1997. Chestnut-collared Longspur (Calcarius ornatus), The Birds of North America Online (A. Poole, Ed.). Ithaca: Cornell Lab of Ornithology. [online] URL: http://bna.birds.cornell.edu/bna/species/288

Jones, S. L., and J. E. Cornely. 2002. Vesper Sparrow (Pooecetes gramineus), The Birds of North America Online (A. Poole, Ed.). Ithaca: Cornell Lab of Ornithology. [online] URL: http://bna.birds.cornell.edu/bna/species/624

Lloyd, J. D., and T. E. Martin. 2005. Reproductive success of chestnut-collared longspurs in native and exotic grassland. The Condor 107:363-374.

Lowther, P. E. 2005. Le Conte's Sparrow (Ammodramus leconteii), The Birds of North America Online (A. Poole, Ed.). Ithaca: Cornell Lab of Ornithology. [online] URL: http://bna.birds.cornell.edu/bna/species/224

Martin, P. A., and D. J. Forsyth. 2003. Occurrence and productivity of songbirds in prairie farmland under conventional versus minimum tillage regimes. Agriculture, Ecosystems and Environment 96:107-117.

Martin, S. G. and T. A. Gavin. 1995. Bobolink (Dolichonyx oryzivorus), The Birds of North America Online (A. Poole, Ed.). Ithaca: Cornell Lab of Ornithology. [online] URL: http://bna.birds.cornell.edu/bna/species/176 
Martin, J. W., and J. R. Parrish. 2000. Lark Sparrow (Chondestes grammacus), The Birds of North America Online (A. Poole, Ed.). Ithaca: Cornell Lab of Ornithology. [online] URL: http://bna.birds.cornell.edu/bna/species/488

McMaster, D. G. and S. K. Davis. 2001. An evaluation of Canada's permanent cover program: habitat for grassland birds? Journal of Field Ornithology 72:195-210.

Owens, R. A., and M. T. Myres. 1973. Effects of agriculture upon populations of native passerine birds of and Alberta fescue grassland. Canadian Journal of Zoology 51:697-713.

Rotenberry, J. T., M. A. Patten, and K. L. Preston. 1999. Brewer's Sparrow (Spizella breweri), The Birds of North America Online (A. Poole, Ed.). Ithaca: Cornell Lab of Ornithology. [online] URL: http://bna.birds.cornell.edu/bna/species/390

Shane, T. G. 2000. Lark Bunting (Calamospiza melanocorys), The Birds of North America Online (A. Poole, Ed.). Ithaca: Cornell Lab of Ornithology. [online] URL: http://bna.birds.cornell.edu/bna/species/542

Vickery, P. D. 1996. Grasshopper Sparrow (Ammodramus savannarum), The Birds of North America Online (A. Poole, Ed.). Ithaca: Cornell Lab of Ornithology. [online] URL: http://bna.birds.cornell.edu/bna/species/239

Wheelwright, N. T. and J. D. Rising. 2008. Savannah Sparrow (Passerculus sandwichensis), The Birds of North America Online (A. Poole, Ed.). Ithaca: Cornell Lab of Ornithology. [online] URL: http://bna.birds.cornell.edu/bna/species/045

With, K. A. 2010. McCown's Longspur (Rhynchophanes mccownii), The Birds of North America Online (A. Poole, Ed.). Ithaca: Cornell Lab of Ornithology. [online] URL: http://bna.birds.cornell.edu/bna/species/096 
Appendix 2. Classification of the Agriculture and Agri-Food Canada Annual Crop Inventory layer.

Table A2.1. Reclassification table for converting Agriculture and Agri-Food Canada (AAFC) Annual Crop Inventory ${ }^{1}$ land cover classifications into two land cover types differentially used by grassland songbirds: cropland, and native and tame grassland/hay.

\begin{tabular}{|c|c|c|}
\hline $\begin{array}{l}\text { AAFC Annual Crop Inventory Raster } \\
\text { Attribute Labels }\end{array}$ & $\begin{array}{l}\text { AAFC Annual Crop } \\
\text { Inventory Raster } \\
\text { Codes }\end{array}$ & $\begin{array}{l}\text { Reclassified } \\
\text { Raster } \\
\text { Attributes }\end{array}$ \\
\hline $\begin{array}{l}\text { Agriculture (generalized), Fallow, } \\
\text { Cereals, Barley, Other Cereals, Millet, } \\
\text { Oats, Rye, Spelt, Triticale, Wheat, } \\
\text { Switchgrass, Winter Wheat, Spring } \\
\text { Wheat, Corn, Tobacco, Ginseng, } \\
\text { Oilseeds, Borage, Camelina, } \\
\text { Canola/Rapeseed, Flaxseed, Mustard, } \\
\text { Safflower, Sunflowers, Soybeans, Pulses, } \\
\text { Peas, Beans, Lentils, Vegetables, } \\
\text { Potatoes, Sugarbeets, Other Vegetables, } \\
\text { Sod, Herbs, Buckwheat, Canaryseeds, } \\
\text { Hemp, Vetch, Other Crops }\end{array}$ & $\begin{array}{l}120,121,130,131, \\
132,133,134,135, \\
136,137,138,139, \\
140,141,145,146, \\
147,148,149,150, \\
151,152,153,154, \\
155,156,157,158, \\
160,162,167,174, \\
175,177,178,179, \\
192,193,194,195, \\
196,197,198,199\end{array}$ & $\begin{array}{l}\text { Cropland (row } \\
\text { crops, low } \\
\text { crops, not } \\
\text { including } \\
\text { orchards, vine } \\
\text { crops) }\end{array}$ \\
\hline Pasture/Forages & 110,122 & $\begin{array}{l}\text { Native and } \\
\text { Tame } \\
\text { Grassland/Hay }\end{array}$ \\
\hline $\begin{array}{l}\text { Cloud, Water, Exposed LandBaren, } \\
\text { Urban/Developed, Greenhouses, } \\
\text { Shrubland, Wetland, Fruits, Berries, } \\
\text { Orchards, Other Fruits, Vineyards, Hops, } \\
\text { Nursery, Forest, Coniferous, Broadleaf, } \\
\text { Mixedwood }\end{array}$ & $\begin{array}{l}10,20,30,34,36 \\
50,80,180,181 \\
188,189,190,191 \\
194,200,210,220 \\
230\end{array}$ & No Data \\
\hline
\end{tabular}

${ }^{1}$ AAFC (2013)

\section{Literature Cited}

AAFC (Agriculture and Agri-Food Canada). 2013. AAFC Annual Crop Inventory. Government of Canada, Ottawa, ON. [online] URL: http://www.data.gc.ca. Accessed 23 October 2014. 
Appendix 3. Mapped baseline predictions (1961-1990) and future projections of climate suitability in North America and Alberta, Canada for the 15 grassland songbirds considered in this study. 


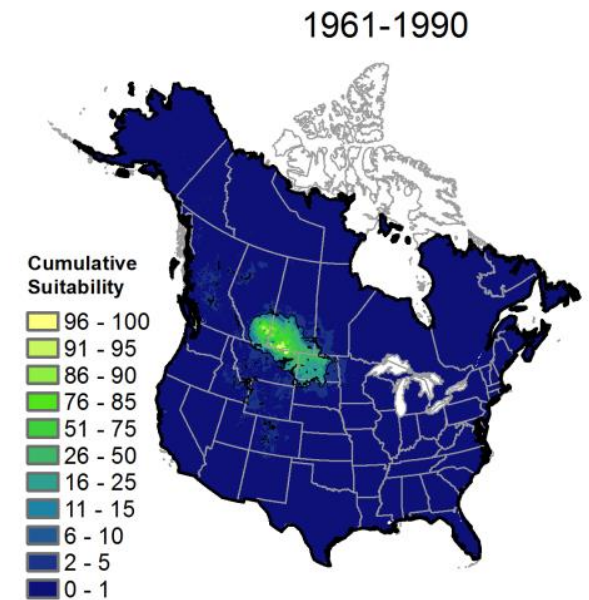

Baird's Sparrow

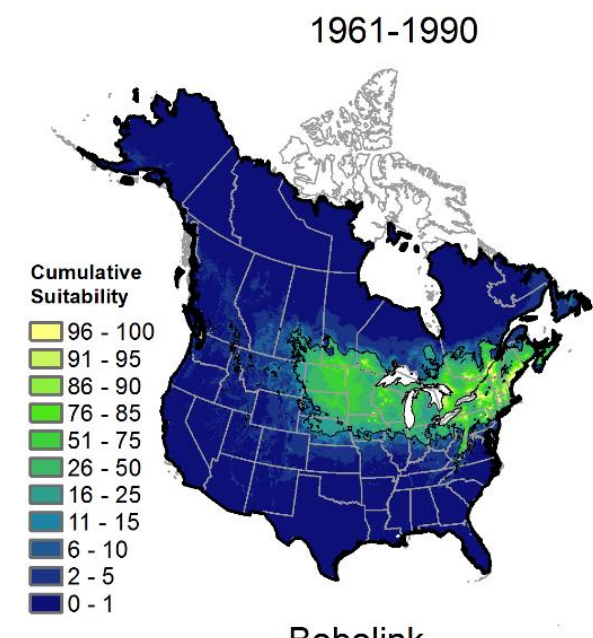

Bobolink
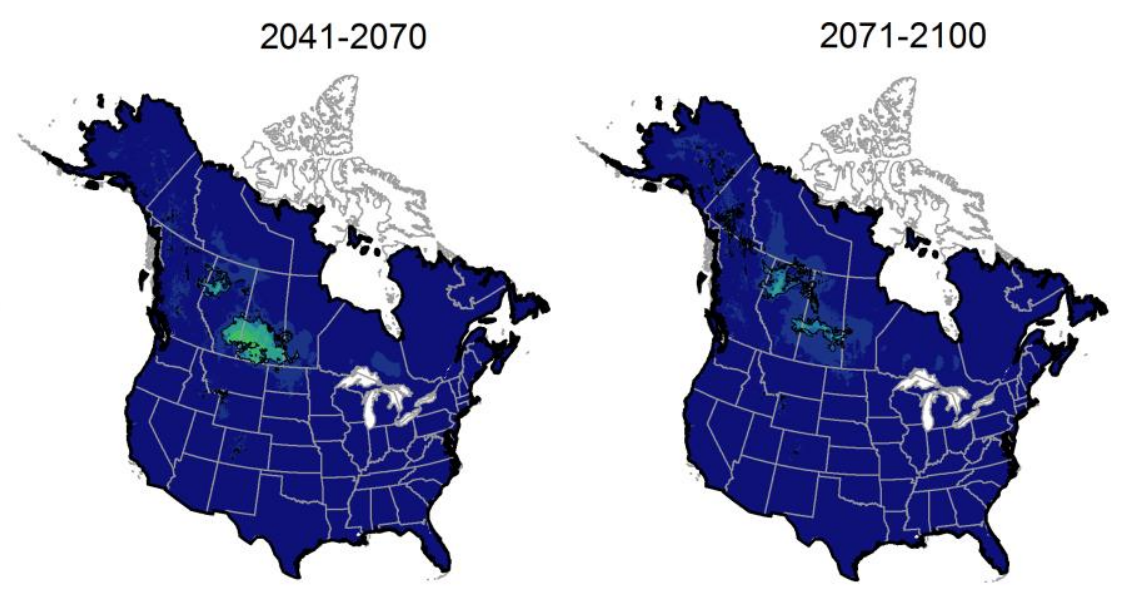

Ensemble of $19 \mathrm{GCMs}$; $\mathrm{A} 2$ emissions scenario
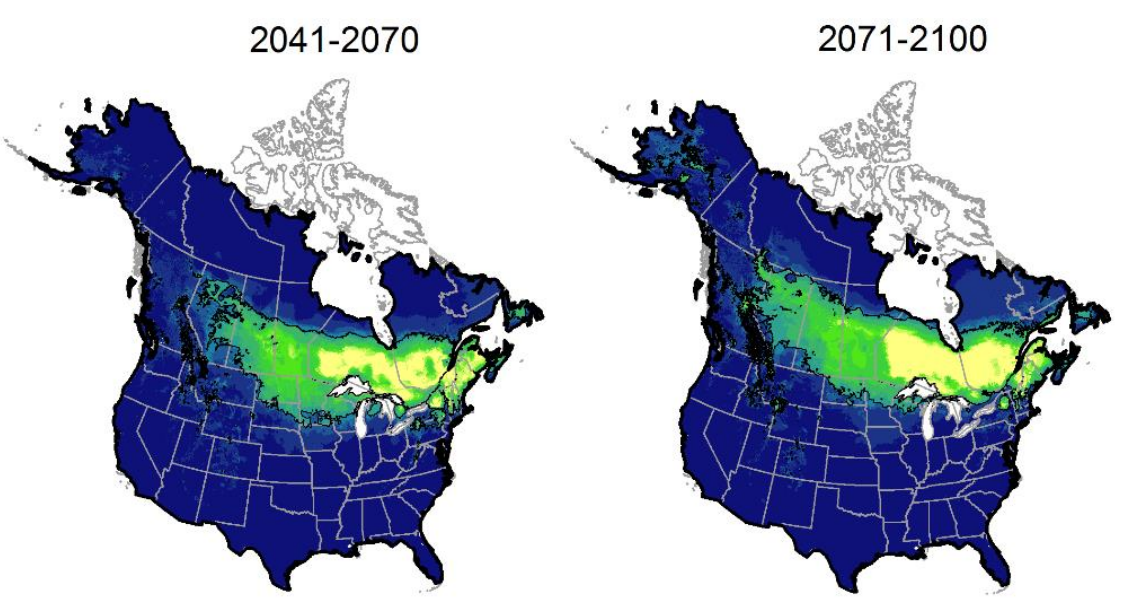

Ensemble of 19 GCMs; A2 emissions scenario 


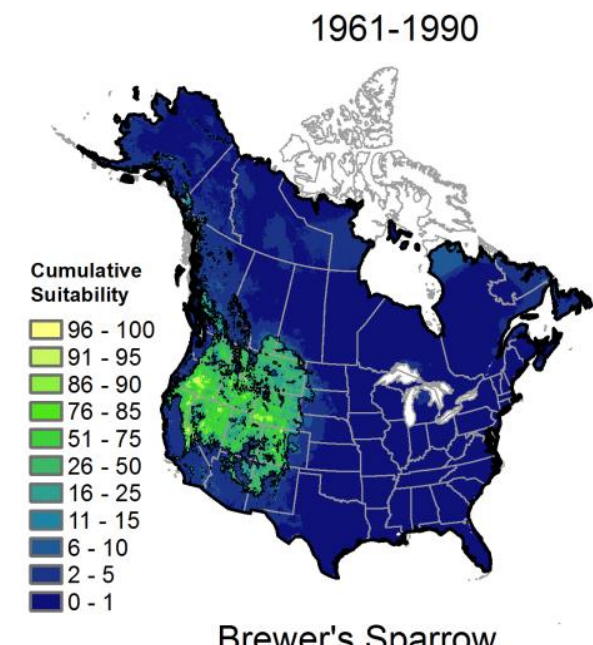

Brewer's Sparrow

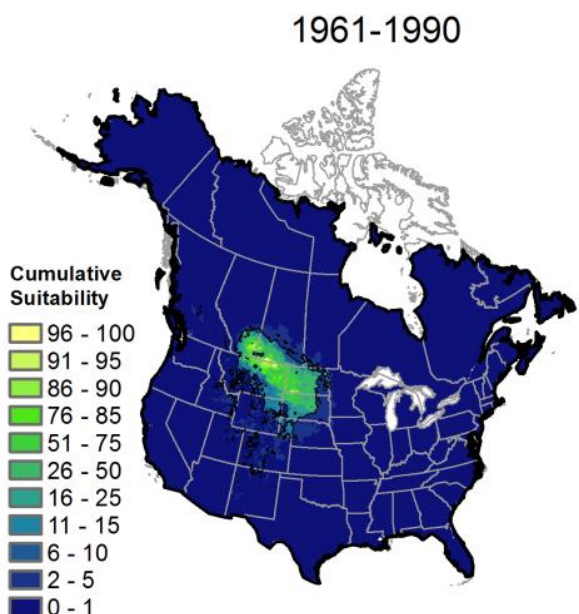

Chestnut-collared Longspur
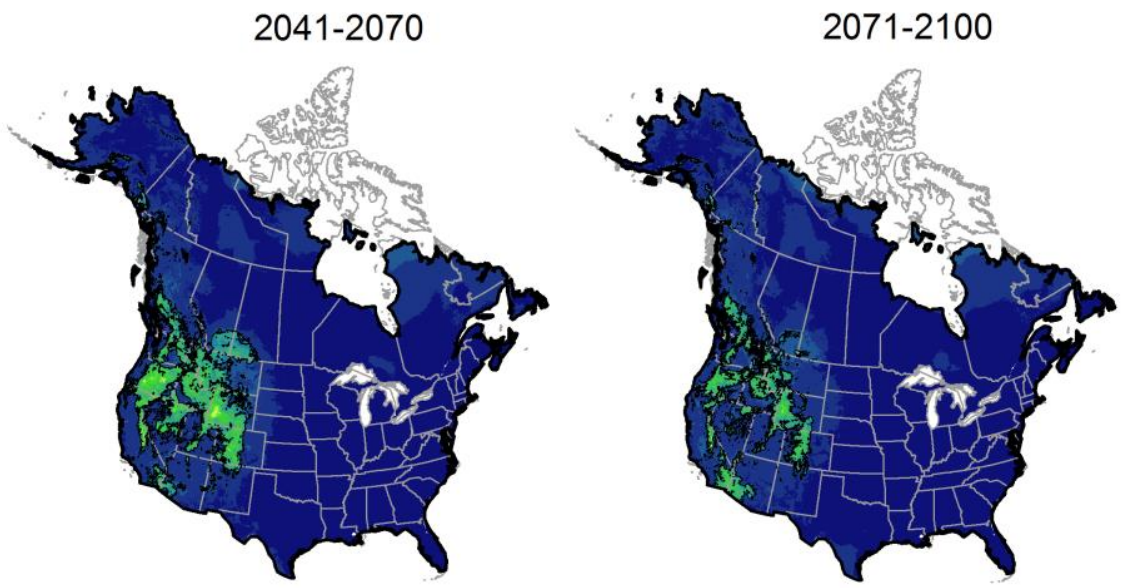

Ensemble of $19 \mathrm{GCMs}$; $\mathrm{A} 2$ emissions scenario
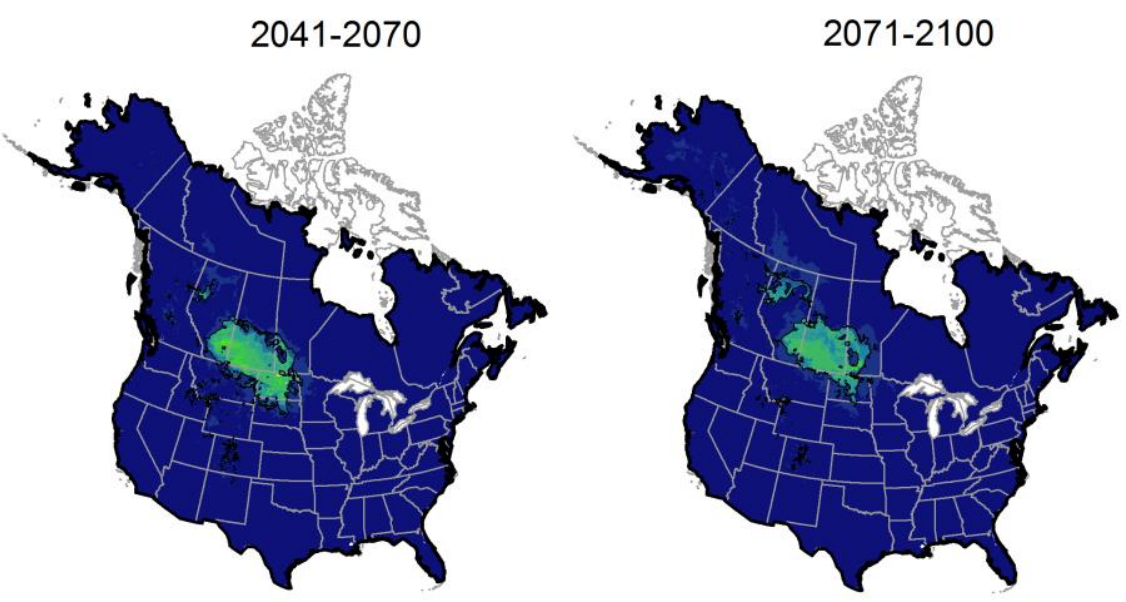

Ensemble of 19 GCMs; A2 emissions scenario 


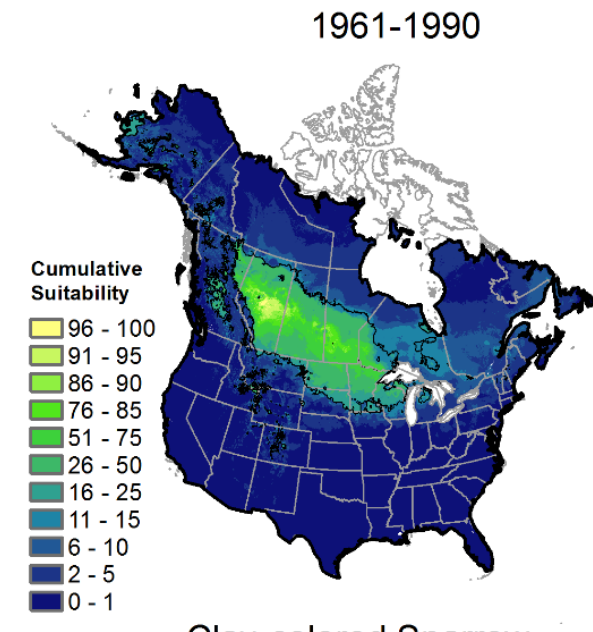

Clay-colored Sparrow

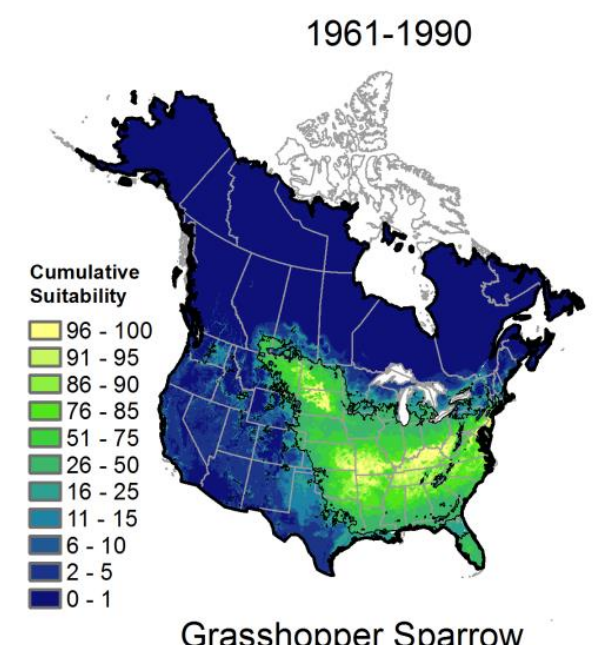

Grasshopper Sparrow
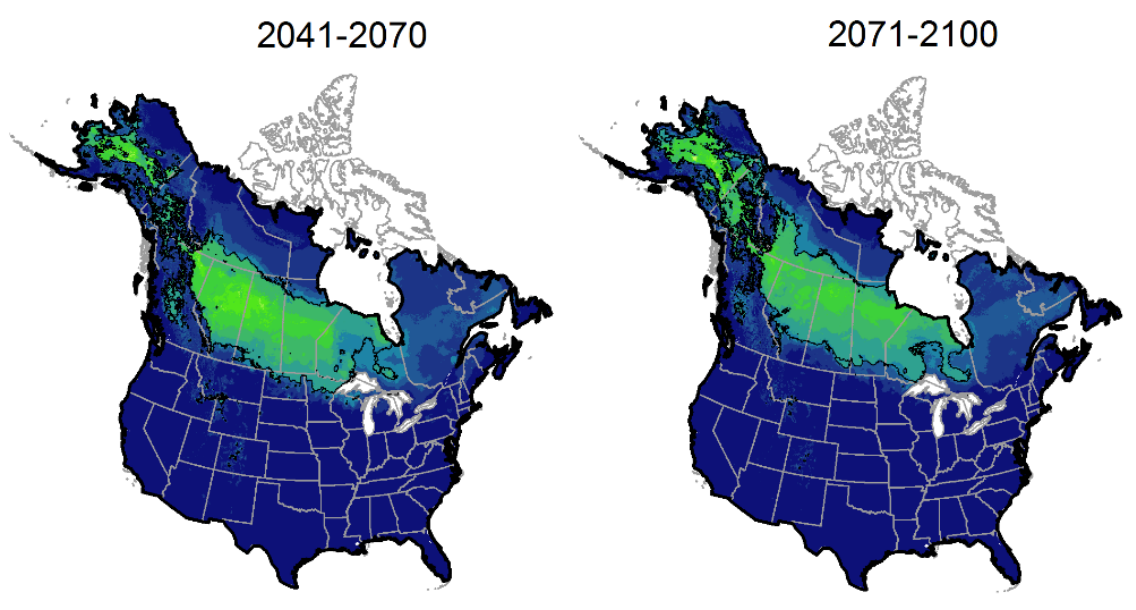

Ensemble of 19 GCMs; A2 emissions scenario
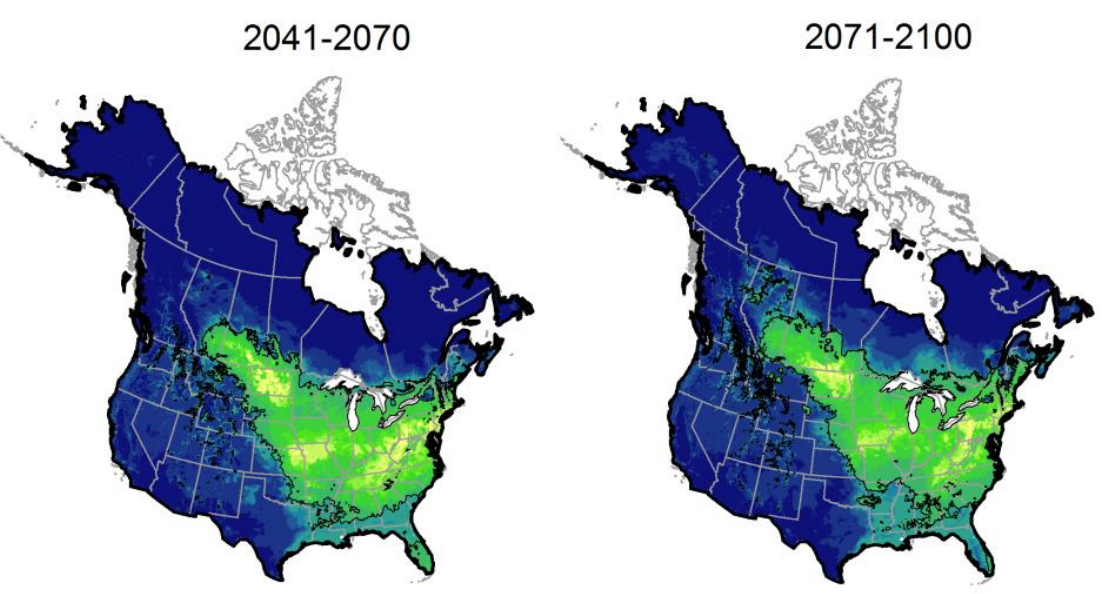

Ensemble of $19 \mathrm{GCMs}$; $\mathrm{A} 2$ emissions scenario 


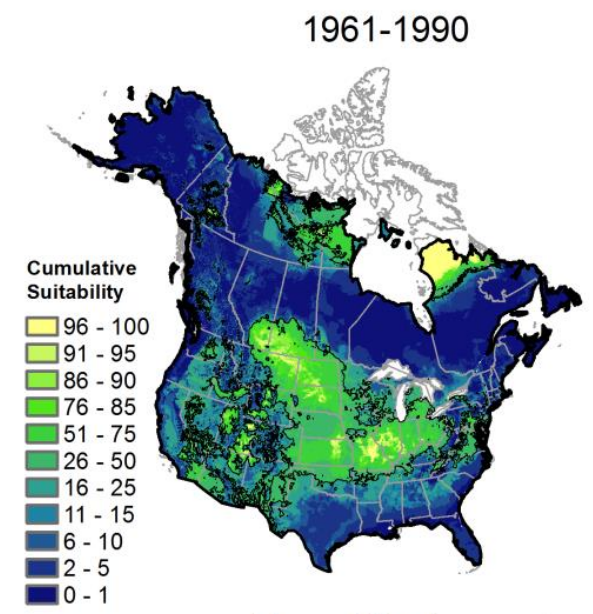

Horned Lark

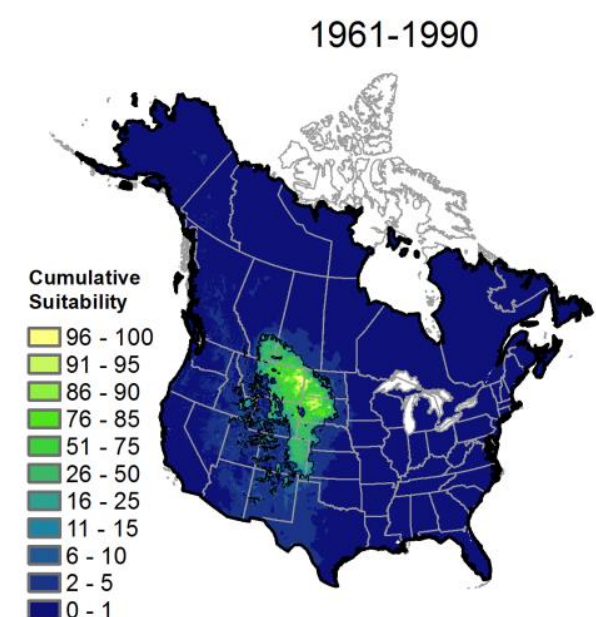

Lark Bunting
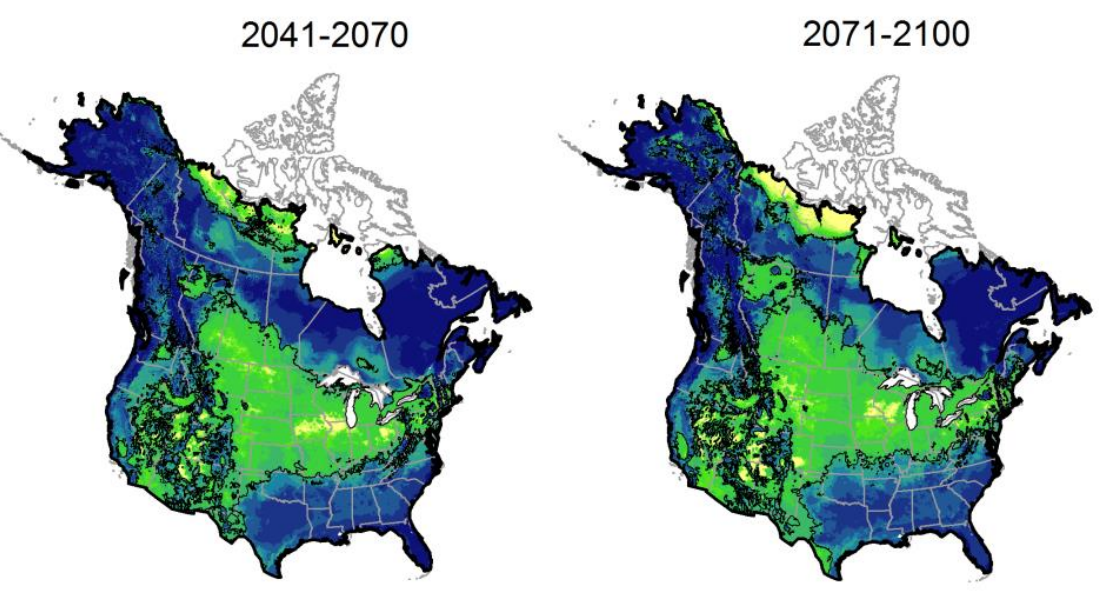

Ensemble of $19 \mathrm{GCMs}$; $\mathrm{A} 2$ emissions scenario
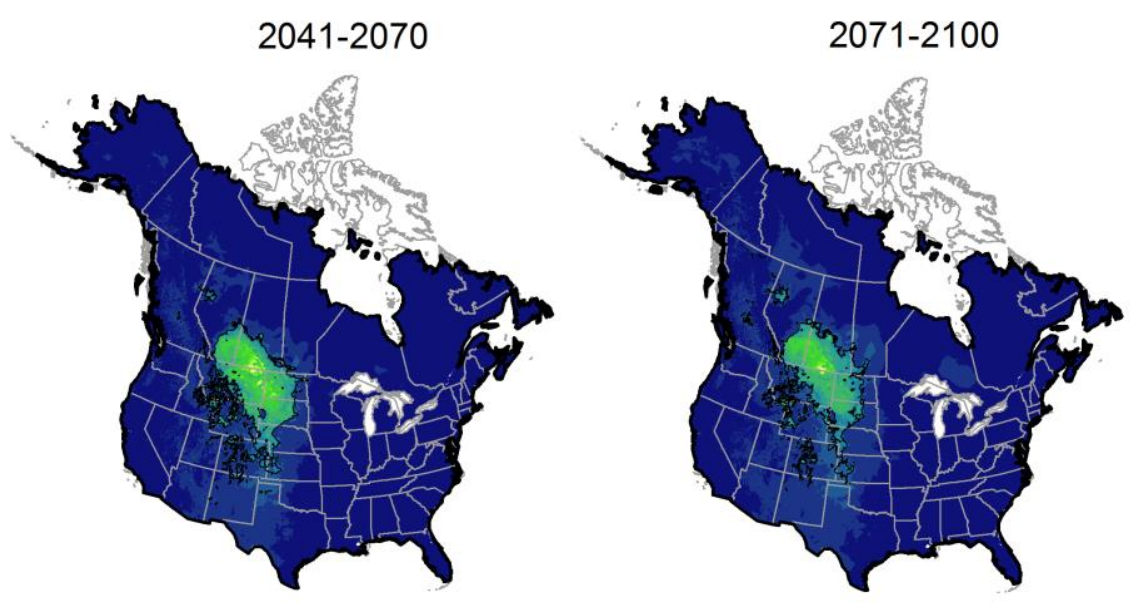

Ensemble of 19 GCMs; A2 emissions scenario 

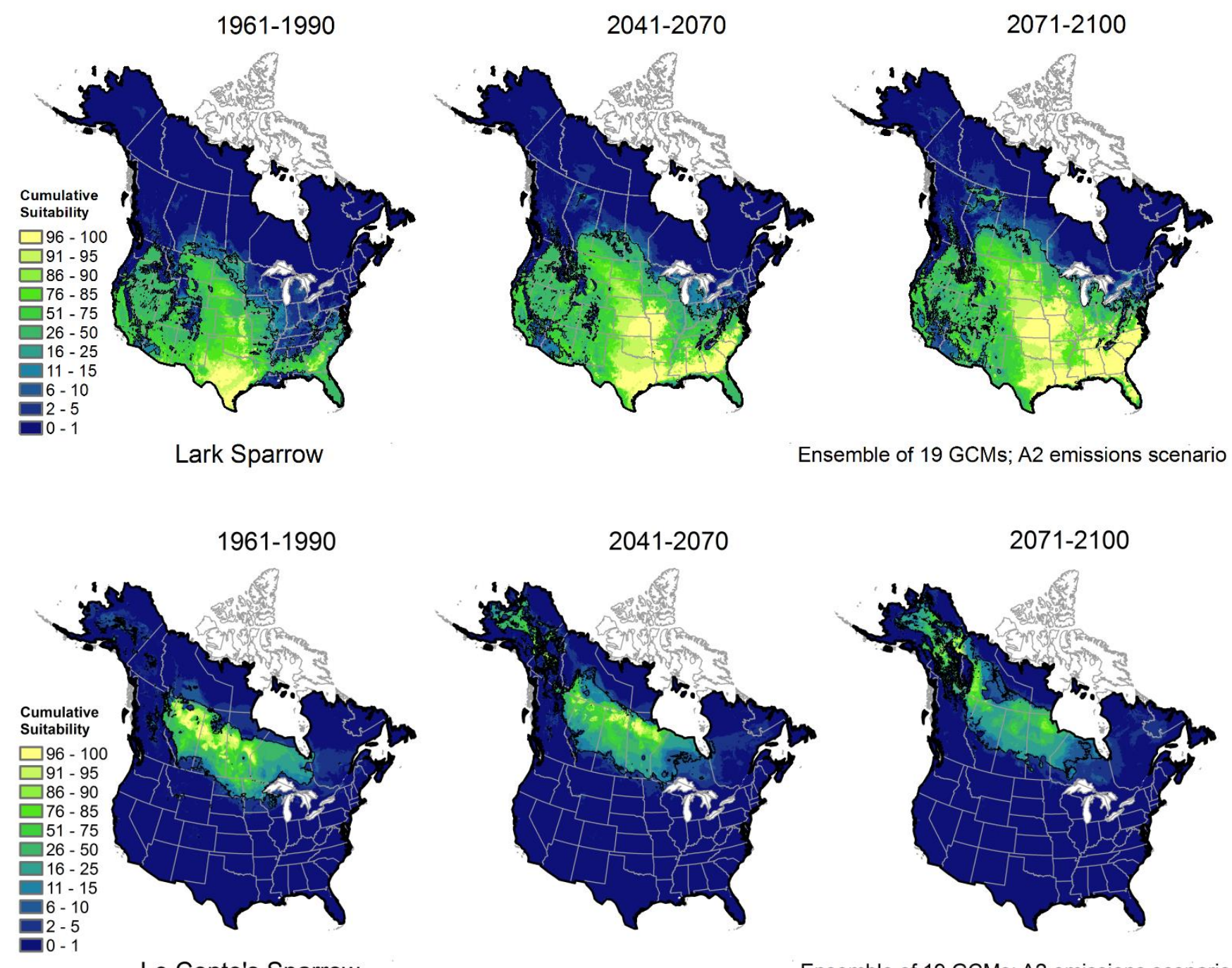

Ensemble of $19 \mathrm{GCMs}$; $\mathrm{A} 2$ emissions scenario 

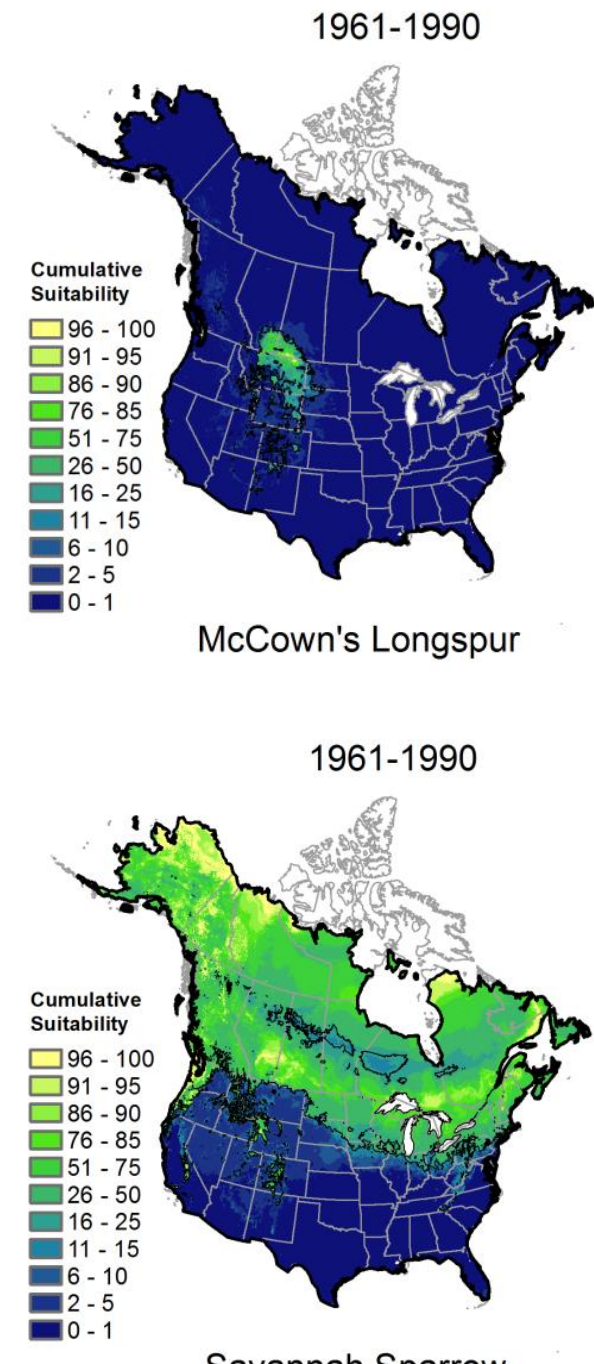

Savannah Sparrow
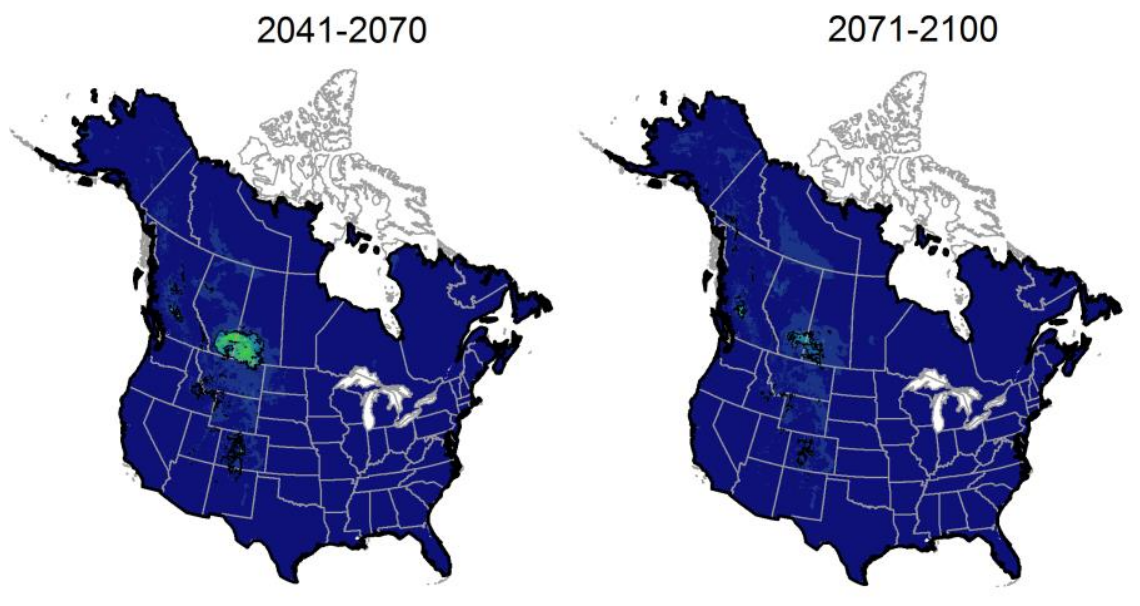

Ensemble of 19 GCMs; A2 emissions scenario
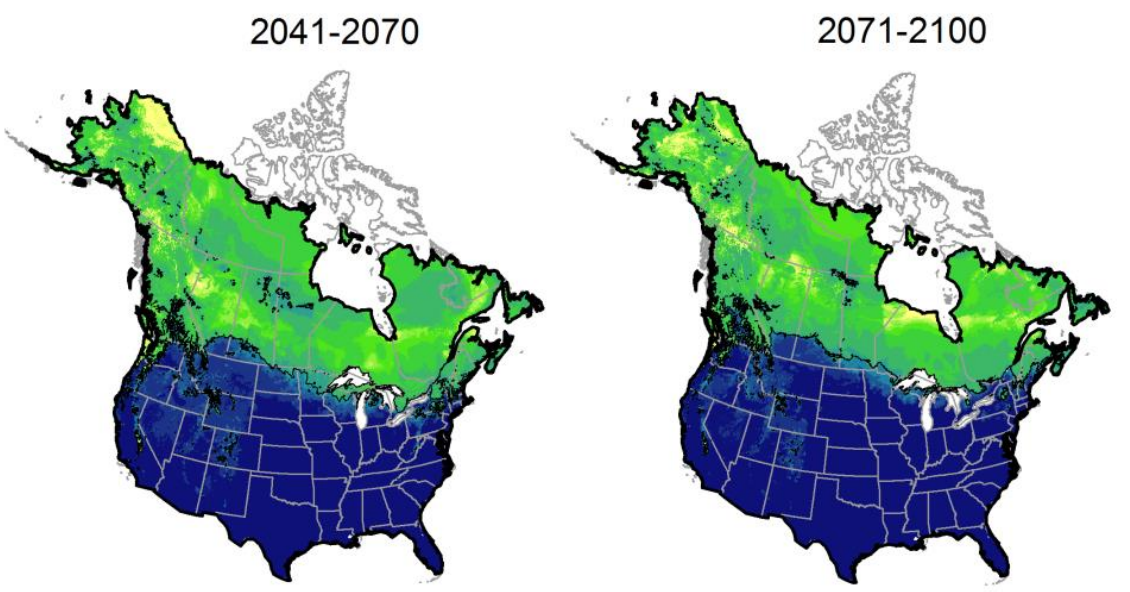

Ensemble of $19 \mathrm{GCMs}$; A2 emissions scenario 

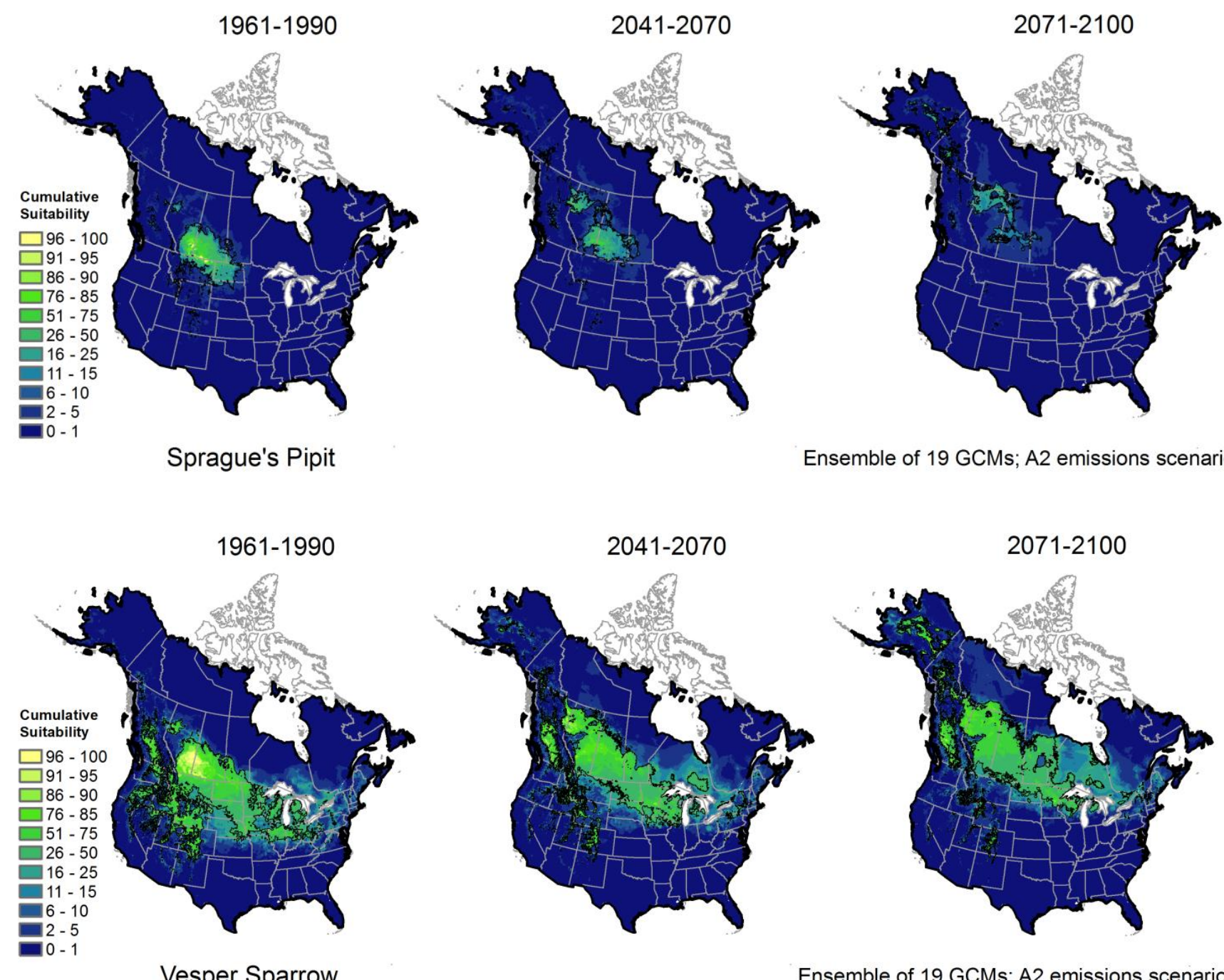

Ensemble of $19 \mathrm{GCMs}$; $\mathrm{A} 2$ emissions scenario 

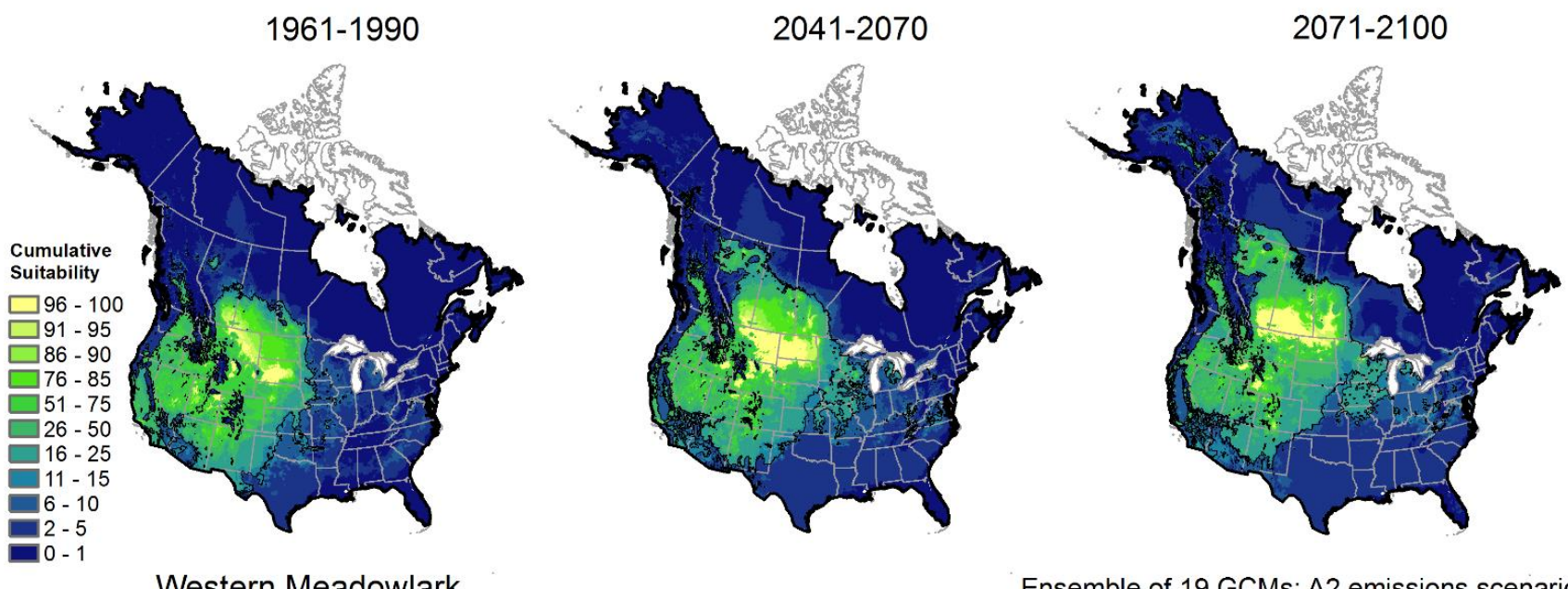

Ensemble of 19 GCMs; A2 emissions scenario

Figure A3.1. Baseline predictions (1961-1990) and future projections (2041-2070 and 2071-2100) of North American climate suitability for 15 grassland songbirds. The black line delineates core suitable climate area for each species as determined by species specific thresholds. Future projections are based on ensemble climate data from 19 global climate models and the A2 SRES emissions scenario. 

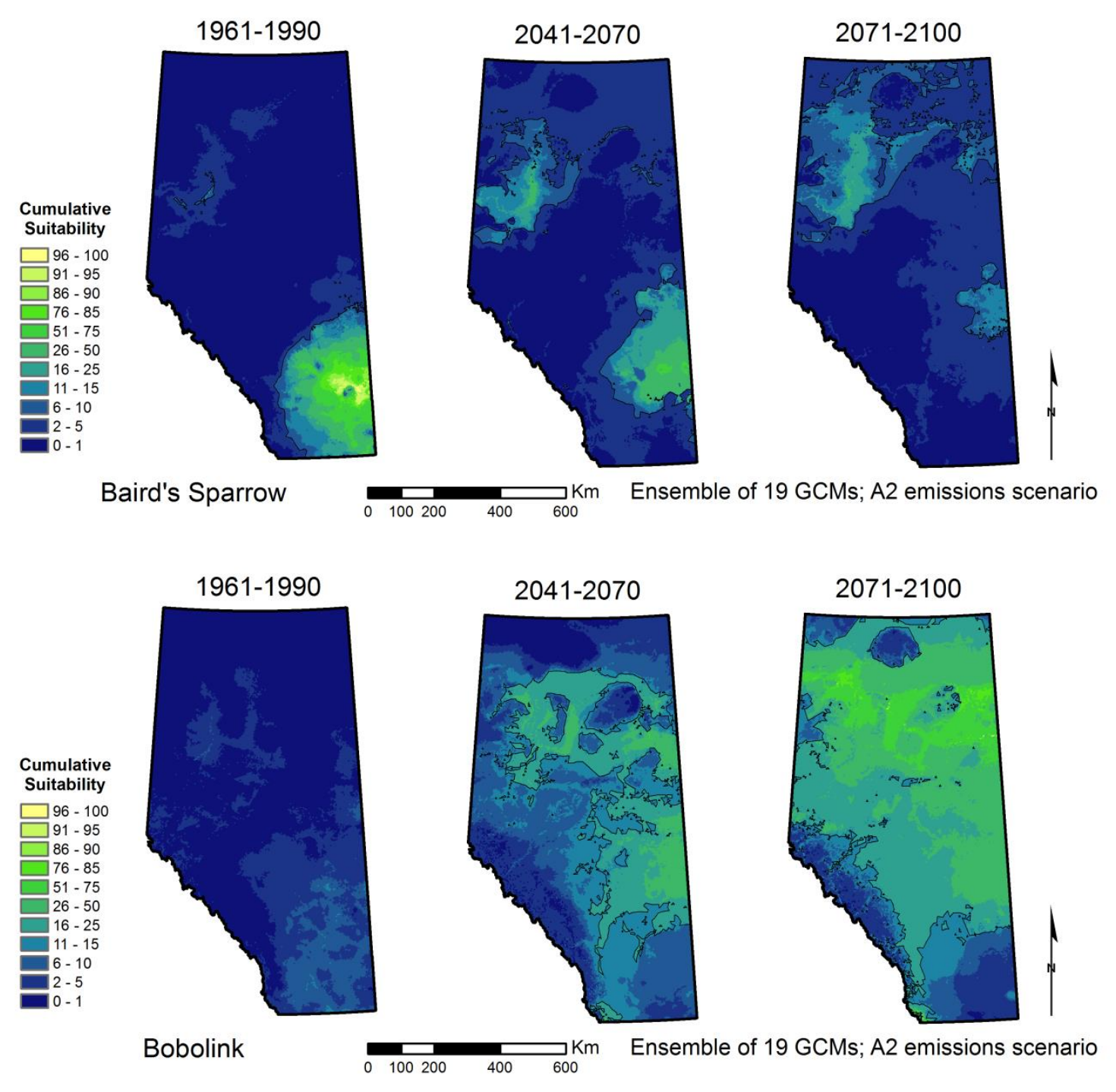

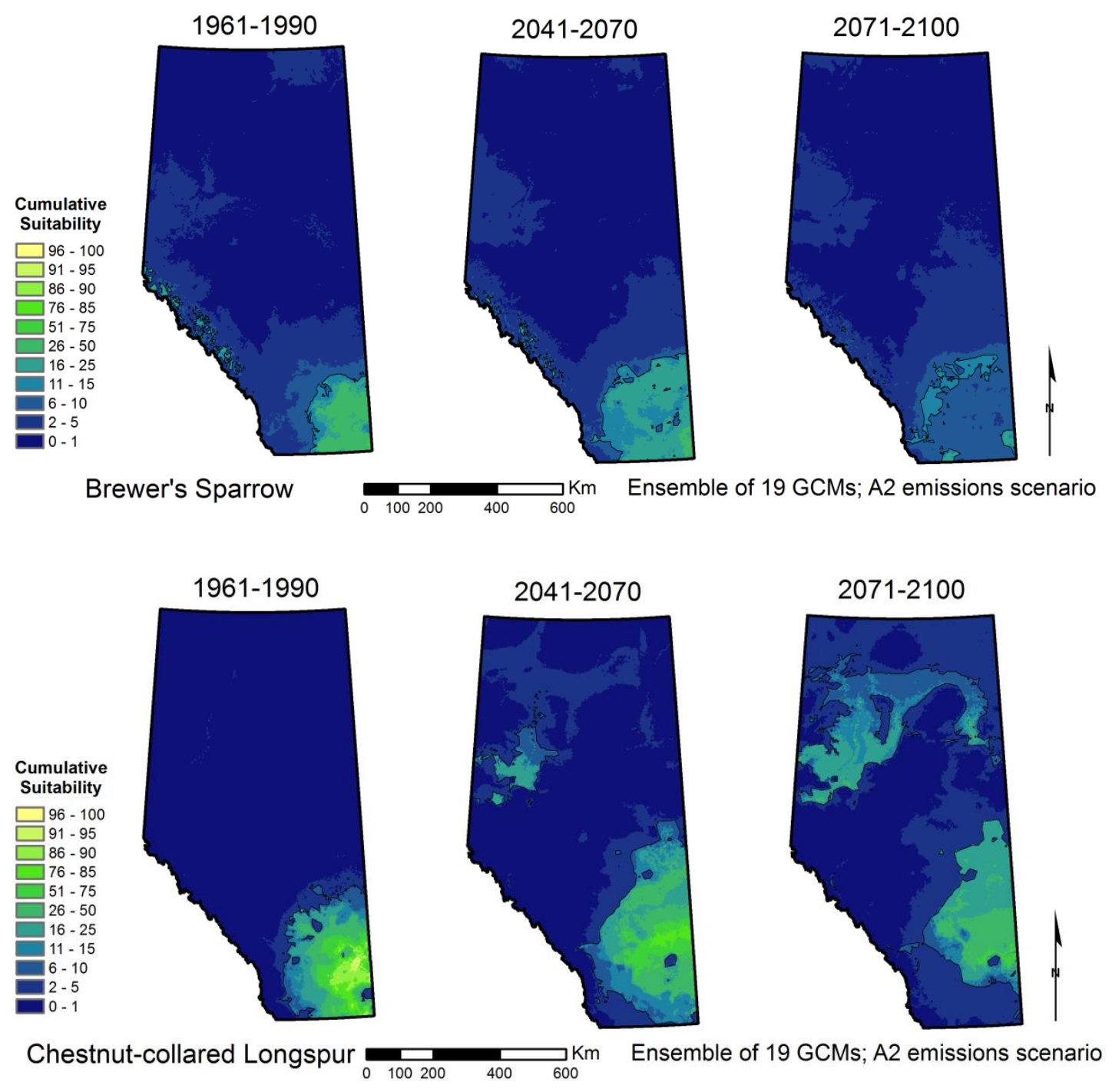

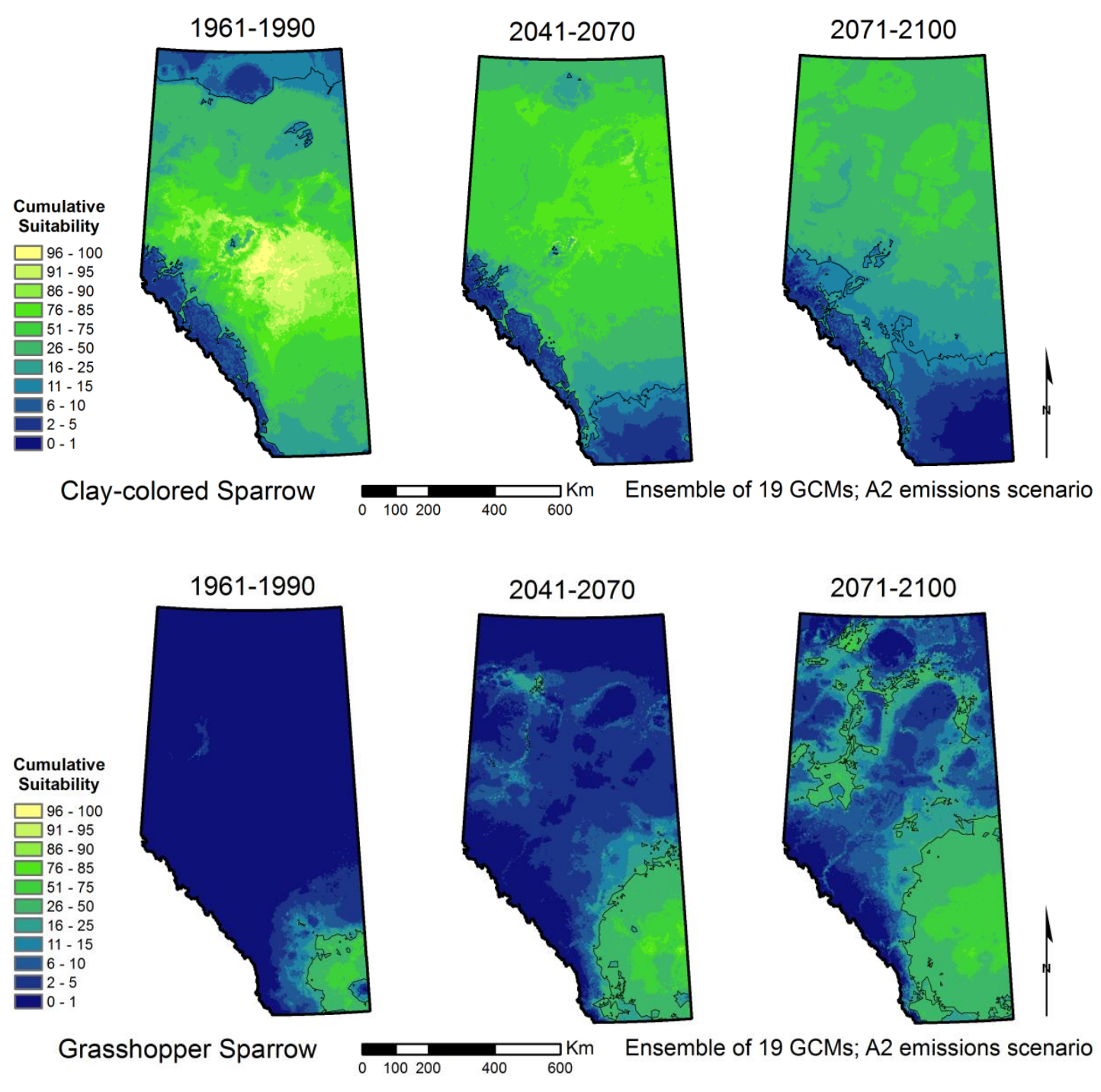

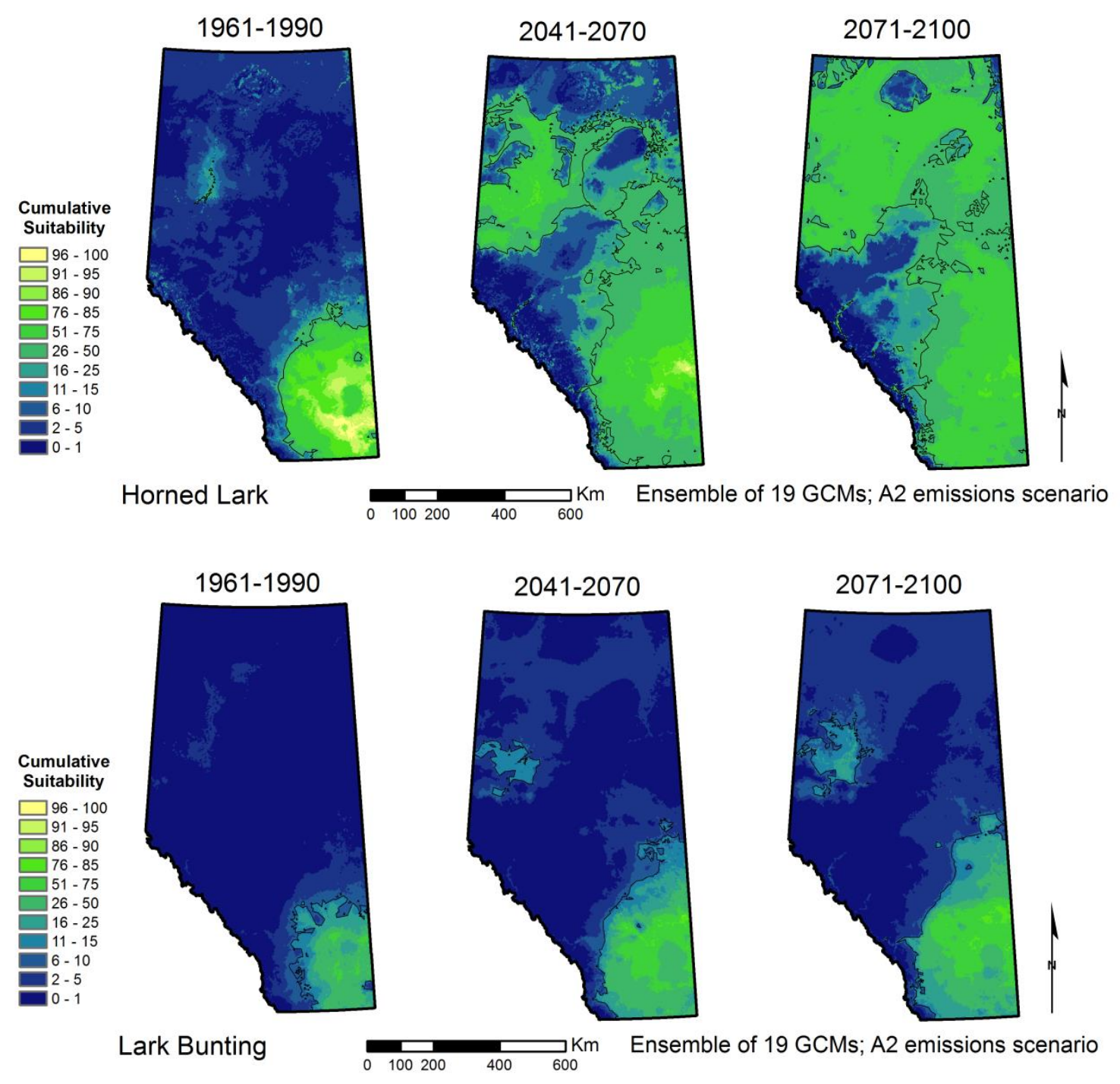

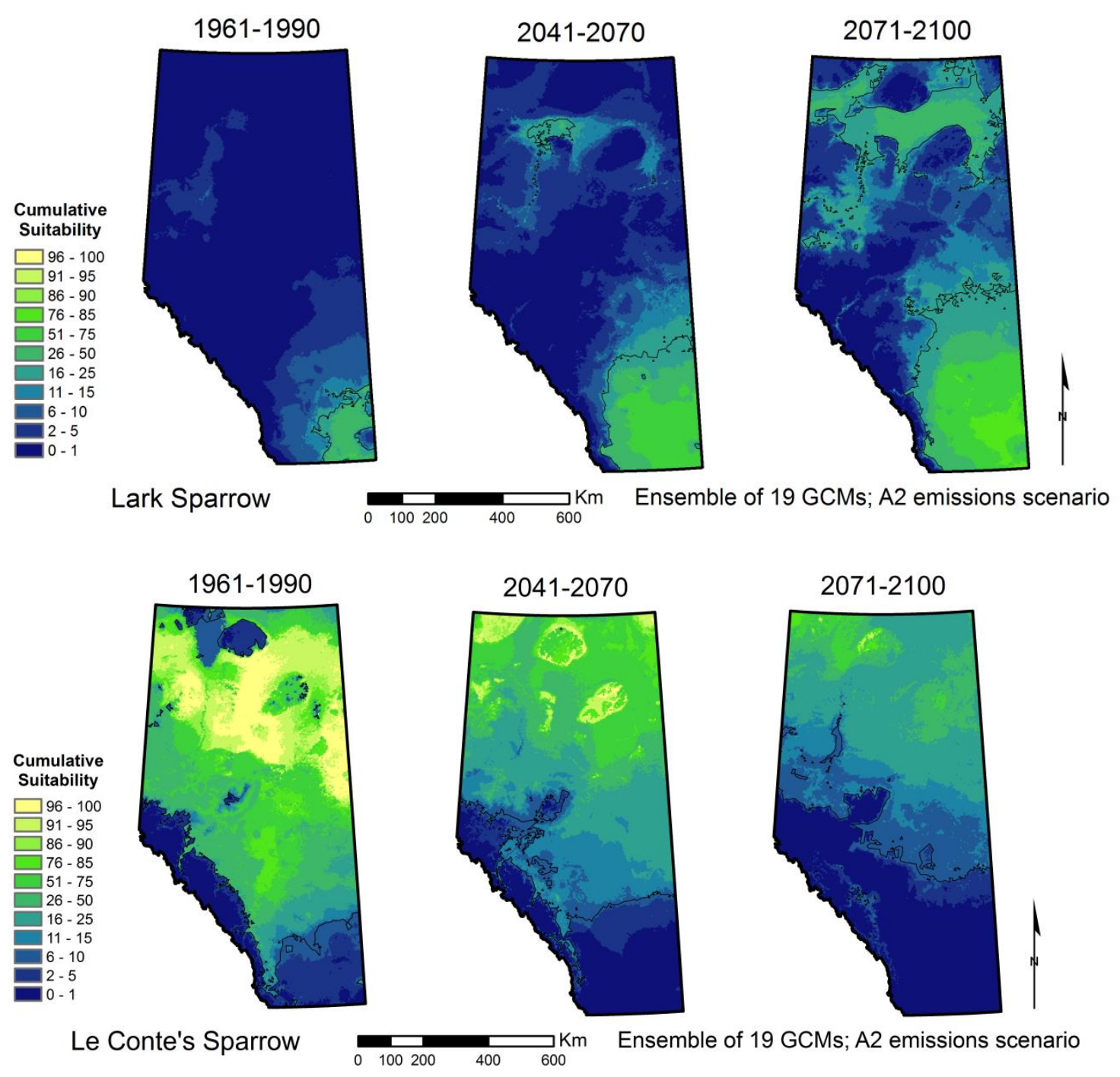

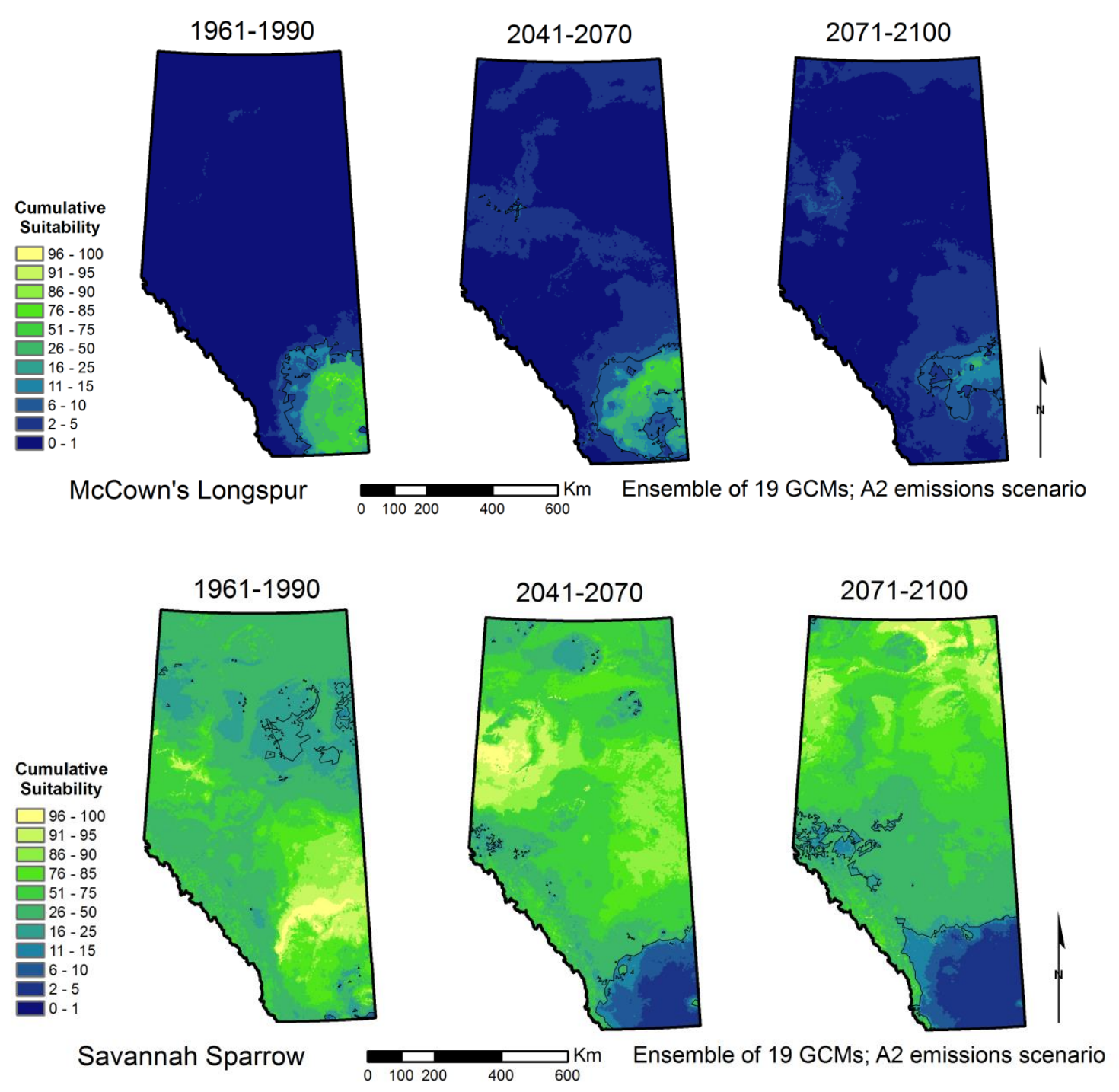

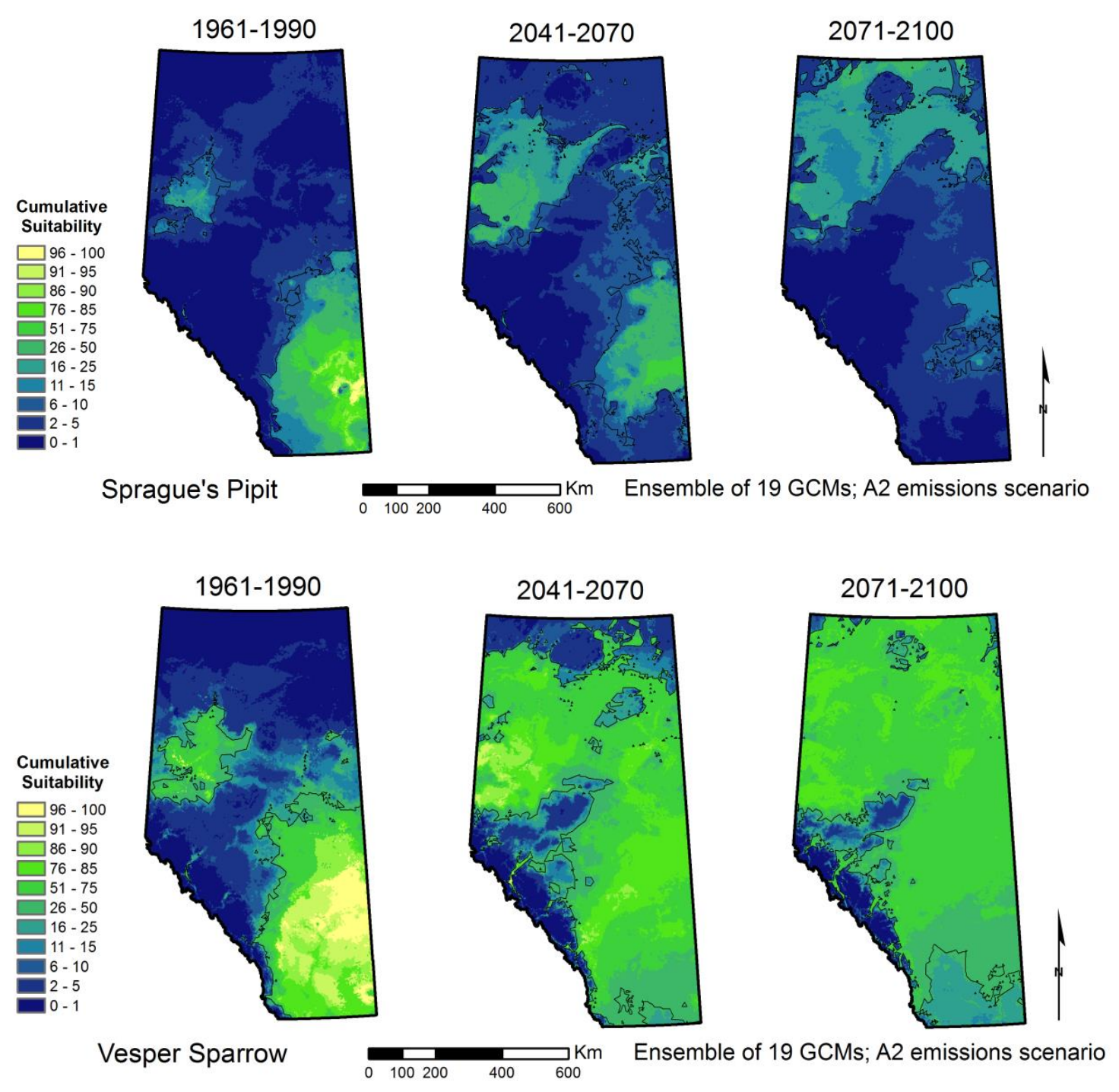


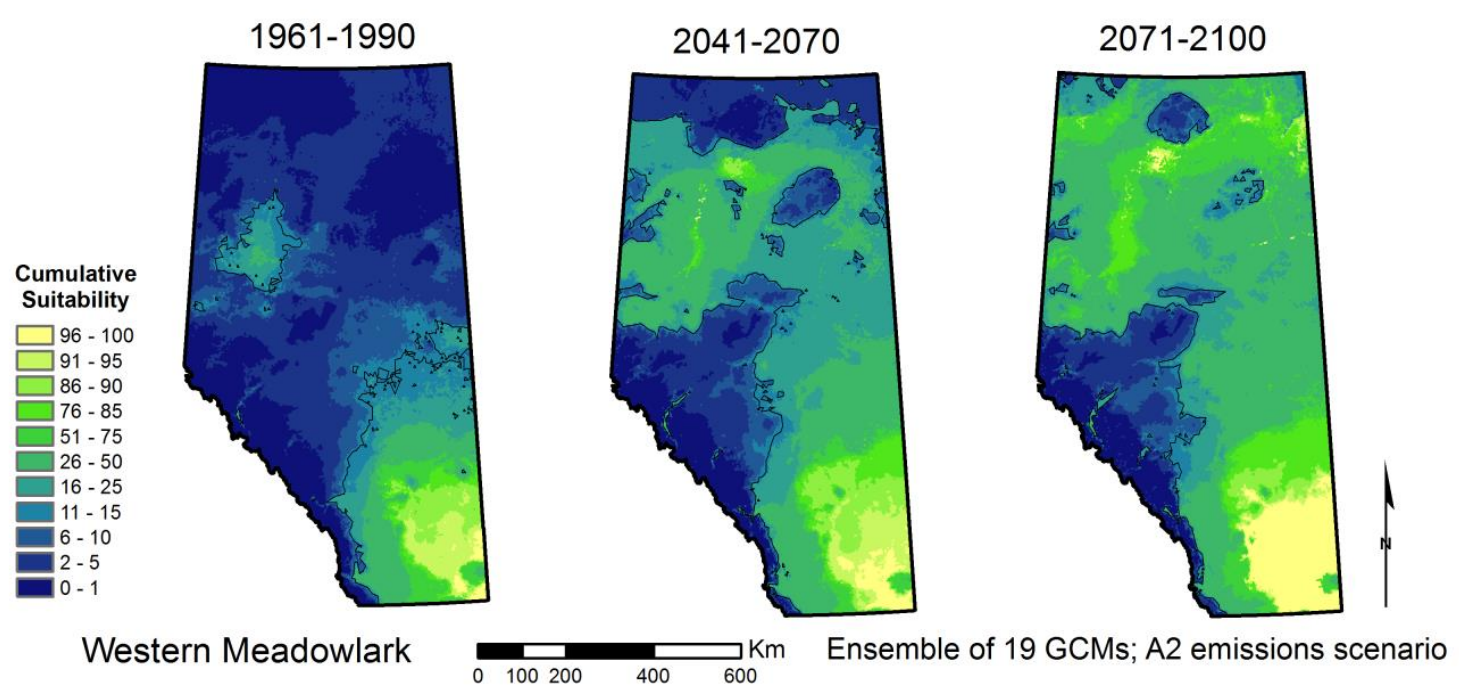

Figure A3.2. Baseline predictions (1961-1990) and future projections (2041-2070 and 2071-2100) of climate suitability for 15 grassland songbirds in Alberta, Canada, based on North American models. The black line delineates core suitable climate area for each species as determined by species specific thresholds. Future projections are based on ensemble climate data from 19 global climate models and the A2 SRES emissions scenario. 
Appendix 4. Ranked predictor variable importance for each species.

Table A4.1 Ranked predictor variable importance for each species based on the average single variable AUC across bootstrap runs. Four letter species codes are presented in Table 1. Predictor variable definitions are presented in Table 2.

\begin{tabular}{|c|c|c|c|c|c|c|c|c|c|c|c|c|c|c|c|}
\hline & BAIS & $\mathrm{BOBO}$ & BRSP & CCLO & CCSP & GRSP & HOLA & LARB & LASP & LCSP & MCLO & SAVS & SPPI & VESP & WEME \\
\hline Annual climate moisture index & 1 & 2 & 3 & 1 & 4 & 2 & 1 & 1 & 1 & 3 & 2 & 3 & 2 & 1 & 1 \\
\hline Mean summer precipitation & 2 & 4 & 1 & 3 & 5 & 4 & 5 & 3 & 7 & 5 & 1 & 7 & 1 & 6 & 3 \\
\hline $\begin{array}{l}\text { Extreme minimum } \\
\text { temperature }\end{array}$ & 3 & 5 & 7 & 4 & 2 & 3 & 4 & 4 & 5 & 2 & 6 & 4 & 3 & 2 & 4 \\
\hline $\begin{array}{l}\text { Summer climate moisture } \\
\text { index }\end{array}$ & 4 & 6 & 2 & 2 & 7 & 6 & 2 & 2 & 2 & 7 & 3 & 5 & 5 & 5 & 2 \\
\hline Growing degree days & 6 & 1 & 5 & 7 & 3 & 1 & 3 & 7 & 3 & 4 & 4 & 2 & 6 & 4 & 5 \\
\hline Continentality & 7 & 7 & 4 & 6 & 6 & 7 & 6 & 5 & 6 & 6 & 7 & 6 & 7 & 7 & 6 \\
\hline
\end{tabular}


Appendix 5. Projected changes in suitable climate in North America.

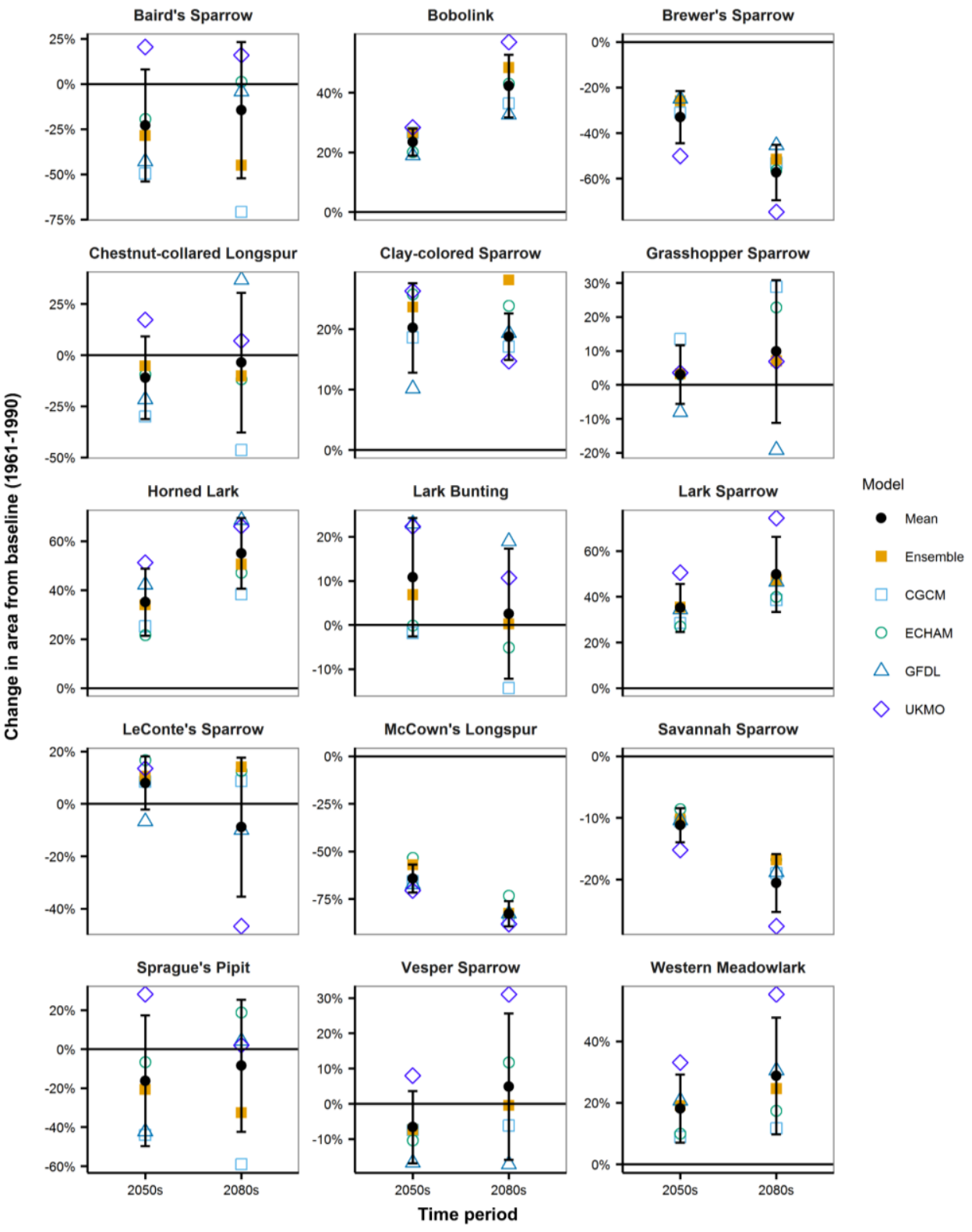

Figure A5.1. Projected changes in core suitable climate area in North America from the historical baseline (1961-1990) for the 2050s (2041-2070) and the 2080s (2071-2100). The mean change ( $\pm 95 \% \mathrm{CI}$; black circles) is determined from the four unique GCMs (CCCMA CGCM3.1; MPI ECHAM5/MPI-OM; GFDL CM2.1; UKMO-HadGEM1; open symbols). Changes in areas projected using ensemble climate data (yellow squares) correspond to the maps in Figure A3.1. 